\title{
Differential responses of peach (Prunus persica) seedlings to elevated ozone are related with leaf mass per area, antioxidant enzymes activity rather than stomatal conductance ${ }^{\text {tr }}$
}

\author{
Lulu Dai ${ }^{\text {a, b, c }}$, Pin Li ${ }^{\text {a, b }}$, Bo Shang ${ }^{\text {a, b }}$, Shuo Liu ${ }^{\text {a, b }}$, Aizhen Yang ${ }^{c}$, Younian Wang ${ }^{\text {, }}$ \\ Zhaozhong Feng a, b, c, * \\ a State Key Laboratory of Urban and Regional Ecology, Research Center for Eco-Environmental Sciences, Chinese Academy of Sciences, Shuangqing Road 18, \\ Haidian District, Beijing, 100085, China \\ ${ }^{\mathrm{b}}$ College of Resources and Environment, University of Chinese Academy of Sciences, Shijingshan District, Beijing 100049, China \\ ${ }^{\mathrm{c}}$ Key Laboratory of Urban Agriculture (North) of Ministry of Agriculture PR China, Beijing University of Agriculture, Beijing 102206, China
}

\section{A R T I C L E I N F O}

\section{Article history:}

Received 9 April 2017

Accepted 25 April 2017

Available online 5 May 2017

\section{Keywords:}

Ozone

Prunus persica

Leaf mass per area

Antioxidant defense

Stomatal conductance

\begin{abstract}
A B S T R A C T
To evaluate the ozone $\left(\mathrm{O}_{3}\right)$ sensitivity among peach tree (Prunus persica) cultivars widely planted in Beijing region and explore the possible eco-physiological response mechanisms, thirteen cultivars of peach seedlings were exposed to either charcoal-filtered air or elevated $\mathrm{O}_{3}\left(\mathrm{E}-\mathrm{O}_{3}\right.$, non-filtered ambient air plus $60 \mathrm{ppb}$ ) for one growing season in open-top chambers. Leaf structure, stomatal structure, gas exchange and chlorophyll $a$ fluorescence, photosynthetic pigments, antioxidant defense system and lipid peroxidation were measured in three replicated chambers. Results showed that $\mathrm{E}_{-} \mathrm{O}_{3}$ significantly reduced abaxial epidemis thickness, but no effects on the thicknesses of adaxial epidemis, palisade parenchyma and spongy parenchyma. Stomatal area, density and conductance were not significantly affected by $\mathrm{E}^{-} \mathrm{O}_{3} . \mathrm{E}-\mathrm{O}_{3}$ significantly accelerated leaf senescence, as indicated by increased lipid peroxidation and more declines in light-saturated photosynthetic rate and pigments contents. The reduced ascorbate content (ASC) was decreased but antioxidant enzyme activity (CAT, APX and SOD) and total antioxidant capacity (TAC) were significantly increased by $\mathrm{E}^{-\mathrm{O}_{3}}$ among cultivars. The cultivars with visible symptoms also had more reductions in net photosynthetic rate than those without visible symptoms. Ozone sensitivity among cultivars was strongly linked to leaf mass per area (LMA), antioxidant enzymes activity e.g. SOD, APX rather than stomatal parameters (stomatal area, density and conductance) and ASC. Results could provide a theoretical basis for selecting and breeding the ozoneresistant cultivars of peach trees grown in high $\mathrm{O}_{3}$-polluted regions.
\end{abstract}

() 2017 Elsevier Ltd. All rights reserved.

\section{Introduction}

Ground-level ozone $\left(\mathrm{O}_{3}\right)$ is considered as one of the most phytotoxic air pollutant due to its significant damage to the plants and ecosystem services worldwide (Paoletti et al., 2010). With the fast industrialization and urbanization in the last three decades, the ground-level ozone $\left(\mathrm{O}_{3}\right)$ is increasing at a rate of approximately $0.5-2 \%$ per year over the midlatitudes of the Northern Hemisphere

\footnotetext{
This paper has been recommended for acceptance by Dr. Yong Sik Ok.

* Corresponding author. State Key Laboratory of Urban and Regional Ecology, Research Center for Eco-Environmental Sciences, Chinese Academy of Sciences, Shuangqing Road 18, Haidian District, Beijing, 100085, China.

E-mail address: fzz@rcees.ac.cn (Z. Feng).
}

(IPCC, 2013). In many regions of China, high levels of $\mathrm{O}_{3}$ have been observed (Wang et al., 2010, 2012; Cooper et al., 2014) and are expected to increase further as NOx precursors are increasing (Feng et al., 2015). The highest hourly ozone value was observed as 316 ppb at Jinan, Shandong Province (Yin et al., 2004). At Miyun, located at the Northeast edge of Beijing, the 95th percentile of daily $\mathrm{O}_{3}$ concentration ranged from $100 \mathrm{ppb}$ to $162 \mathrm{ppb}$ during April to September based on in situ observations (Cooper et al., 2014). Yuan et al. (2015) also reported that the daily mean ambient $\mathrm{O}_{3}$ concentration was $71.3 \mathrm{ppb}$, and the maximum hourly peak concentration was $173.6 \mathrm{ppb}$ in the northwest areas of Beijing during June to September 2014. Numerous experimental studies showed that ambient $\mathrm{O}_{3}$ concentrations with an average of $40 \mathrm{ppb}$ have significantly decreased the yield of crops (rice, wheat, soybean and 
potato) and total biomass of trees by $10 \%$ and $7 \%$ compared with low ozone concentrations air, respectively (Feng and Kobayashi, 2009; Wittig et al., 2009). Furthermore, high $\mathrm{O}_{3}$ concentrations also caused many physiological and biochemical changes in plants, for instance, decreased photosynthesis, stomatal closure, chlorophyll degradation, metabolic disorder, accelerated senescence and weaken defense against pests and diseases with or without visible foliar injury (Feng et al., 2014; Hoshika et al., 2015; Li et al., 2016; Matyssek et al., 2010; Zhang et al., 2012).

Peach tree (Prunus persica) is originated from China and widely cultivated in China. The harvested area and production in China were over 726,068 ha and 12,423,700 tonnes in 2014 (FAOstat, 2014). Peach peculiarities of flavor and aroma result from a balance of sugars, organic acids, phenolic compounds, carotenoids and volatile compounds, making it an appreciated fruit of great commercial importance (Gil et al., 2002). Although there are many studies about the negative impact of $\mathrm{O}_{3}$ on woody species (Calatayud et al., 2011; Feng et al., 2011; Haberer et al., 2007; Kontunen-Soppela et al., 2010), very little is known about effect of $\mathrm{O}_{3}$ on orchard trees, especially on the peach trees to date. Mccool and Musselman (1990) and Badiani et al. $(1993,1996)$ found that elevated $\mathrm{O}_{3}$ restrained the growth of peach to some magnitudes in America and Europe, respectively, and current $\mathrm{O}_{3}$ level was over the critical level of peach growth. However, neither of them explored the mechanism on the difference in response to $\mathrm{O}_{3}$ among cultivars. May-September is the peak of $\mathrm{O}_{3}$ concentration in Northern China every year, and the period is also the crucial growth season of peach. Due to high overlapping between them, the growth of peach tree may be affected by high $\mathrm{O}_{3}$ concentration. Furthermore, the presence of $\mathrm{O}_{3}$ visible symptoms in Prunus persica $f$. duplex was observed in field surveys around Beijing (Feng et al., 2014). However, whether $\mathrm{O}_{3}$ affects growth, physiological and biochemical characteristics of peach tree in China has not been explored to date.

There is a large variation in the sensitivity to $\mathrm{O}_{3}$ between genotypes or species. Generally, evergreen genotypes/species are more tolerant to $\mathrm{O}_{3}$ than deciduous genotypes/species (Calatayud et al., 2010; Zhang et al., 2012), and needle-leaf vegetation is more tolerant than broadleaved plants (LRTAP, 2010). The internal mechanism on the $\mathrm{O}_{3}$ sensitivity has been controversial. Some studies found the $\mathrm{O}_{3}$ sensitivity was associated with high stomatal conductance $\left(g_{s}\right)$ (Paoletti, 2006; Wittig et al., 2007), but others argued that it depended on antioxidant levels rather than $g_{s}$ (Feng et al., 2016; Nali et al., 2004). Li et al. (2016) compared 29 deciduous and evergreen woody species with different sensitivity to $\mathrm{O}_{3}$ and found that both leaf morphology and antioxidant levels were related to $\mathrm{O}_{3}$ sensitivity. Furthermore, many studies have confirmed that the $\mathrm{O}_{3}$-induced responses of antioxidant metabolism varied by species or cultivars in the detoxification of reactive oxygen species (ROS), depending on the concentration of $\mathrm{O}_{3}$ and the duration of the fumigation, e.g. acute vs. chronic ozone exposure (Betzelberger et al., 2010; Burkey et al., 2003; Feng et al., 2011). Generally, acute exposure to relatively high $\mathrm{O}_{3}$ concentrations often caused leaf lesions due to programmed cell death and induced an increase in antioxidant metabolism. In the chronic exposure to relatively low $\mathrm{O}_{3}$ concentrations, there is still some dispute about the antioxidant response to $\mathrm{O}_{3}$. Some studies demonstrated that total antioxidant capacity was increased after chronic exposure to elevated $\mathrm{O}_{3}\left(\mathrm{E}-\mathrm{O}_{3}\right)$ in soybean plants (Gillespie et al., 2011), whereas others found that antioxidant pools and key enzymes in the apoplast and leaf tissues of wheat were declined by E-O $\mathrm{O}_{3}$ in an $\mathrm{O}_{3}$-FACE (Feng et al., 2010; Wang et al., 2014a,b). Peach tree consists of nectarines, flat peach, white peach and yellow peach with different leaf traits. Whether there is different response to $\mathrm{O}_{3}$ among cultivars of peach tree is not so clear. Furthermore, it is not clear if factors contributing to $\mathrm{O}_{3}$ sensitivity among cultivars or species also play an important role in different response to $\mathrm{E}-\mathrm{O}_{3}$ among cultivars of the peach tree.

In this study, 13 cultivars of peach seedlings including six nectarines and seven white peaches were exposed to relatively high concentration under local climate conditions. The objectives were (1) to elucidate the eco-physiological response to $\mathrm{O}_{3}$ among cultivars and find the sensitive and tolerant cultivars of peach seedlings and (2) to explore the intrinsic mechanisms on the differences in $\mathrm{O}_{3}$ sensitivity among cultivars of peach seedlings.

\section{Materials and methods}

\subsection{Experiment site and fumigation treatment}

The experiment was conducted in field open-top chambers (OTCs) located at Tangjiapu town $\left(40^{\circ} 45^{\prime} \mathrm{N}, 115^{\circ} 97^{\prime} \mathrm{E}\right)$, Yanqing district, northwest of Beijing, China, $\sim 60 \mathrm{~km}$ from Beijing city. There were two treatments inside six OTCs: one with charcoal-filtered air (CF) in which $\sim 70 \%$ of the $\mathrm{O}_{3}$ in the ambient air was filtered, another with elevated $\mathrm{O}_{3}\left(\mathrm{E}-\mathrm{O}_{3}\right.$, non-filtered ambient air plus extra $60 \mathrm{ppb} \mathrm{O}_{3}$ during fumigation hours). Every treatment had three chambers replicates. $\mathrm{O}_{3}$ fumigation started from 26 June to 30 September with a daily maximum of $10 \mathrm{~h}$ (from 08:00 to 18:00) except rainy days. During the experimental period covering nonfumigated days, the averaged $\mathrm{O}_{3}$ concentration in $\mathrm{CF}$ and $\mathrm{E}-\mathrm{O}_{3}$ was 28.1 and $87.0 \mathrm{ppb}$, respectively, and AOT40 (accumulation of hourly $\mathrm{O}_{3}$ concentration over $40 \mathrm{ppb}$ ) was 2.48 and $50.8 \mathrm{ppm} \mathrm{h}$, respectively (Fig. 1). Ozone was generated from pure oxygen by an electrical discharge $\mathrm{O}_{3}$ generator (HY003, Chuangcheng Co. Jinan, China). A UV absorption $\mathrm{O}_{3}$ analyzer (Model 49i-Thermo, Thermo Scientific, Massachusetts, USA) was used to continuously monitor $\mathrm{O}_{3}$ concentrations inside the OTCs. For each of the 13 cultivars, three replicates were grown in each OTC. Possible confounding influences of within OTC differences in growth conditions were minimized by changing plant positions within each OTC weekly.

\subsection{Plant materials}

Thirteen cultivars of peach seedlings including six nectarines ( $L J Y, 76, R G 27, R G 29, W C$ and $Z C$ ) and seven white peaches (CJ, DDT, GH2, JY, LH9, LHC and W24) were randomly selected in this study, representing a wide range of peach tree cultivated in surrounding areas of Beijing. One-year-old seedlings of the selected cultivars were individually planted into $30 \mathrm{~L}$ plastic pots filled with local loamy soil. The soil was excavated from farmland at $0-10 \mathrm{~cm}$ depth, sieved out by a $0.3 \mathrm{~mm}$ pore mesh and then mixed for homogeneity carefully. All seedlings were manually irrigated at $1-2$ days interval

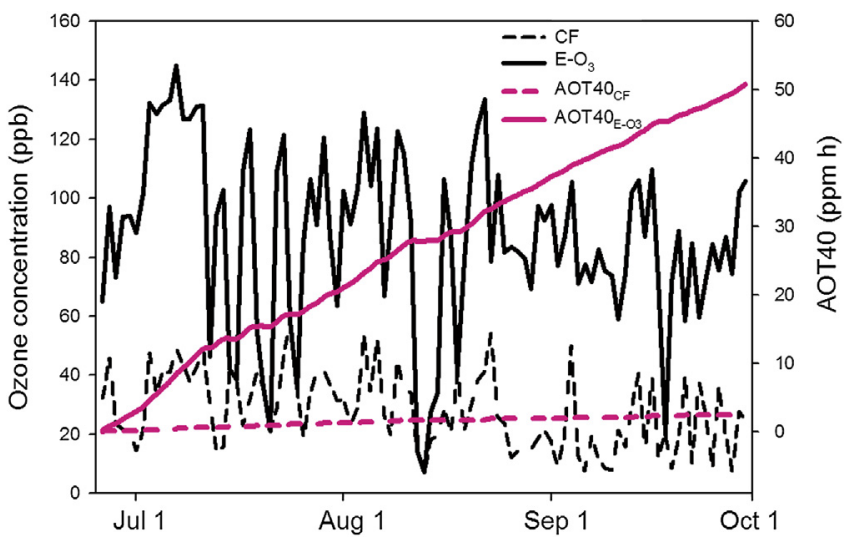

Fig. 1. Variations in $10 \mathrm{~h}(8: 00-18: 00)$ mean $\mathrm{O}_{3}$ concentrations and AOT40 from June 26 to September 30 in charcoal-filtered air $(\mathrm{CF})$ and elevated $\mathrm{O}_{3}\left(\mathrm{E}-\mathrm{O}_{3}\right)$ treatments. 
to keep soil moisture uniform and close to field capacity.

\subsection{Visible $\mathrm{O}_{3}$ injury}

Leaves of each seedling were observed every other day until symptoms first appeared and checked twice every week thereafter. The date of first foliar injury onset was defined when plants in three replicated chambers showed the same foliar symptoms. The onset date of visible foliar injury and the injury performance were recorded. The AOT40 at the initial visible injury onset (AOT40_injury) was calculated following to the approach described by Zhang et al. (2012) and Li et al. (2016). Notably, we did not quantify the severity of visible injury because it needs much experience and professional techniques.

\subsection{Leaf structure}

For leaf anatomical traits, six leaves per plant were sampled according to the method of Li et al. (2016). In brief, leaf samples were fixed with $4 \%$ mixed fixative of paraformaldehyde and glutaraldehyde for $24 \mathrm{~h}$ at $4{ }^{\circ} \mathrm{C}$ and washed three times for $15 \mathrm{~min}$ with $0.1 \mathrm{M}$ phosphate-buffered saline ( $\mathrm{pH} 7.2)$. For microscopy examinations, samples were cut with a freezing microtome (CM 1325; Leica, Wetzlar, Germany) and sections were stained with safranin-fast green. The thickness of adaxial epidermis, abaxial epidermis, palisade and spongy parenchyma of the sections was photographed using an Olympus CX 41 fluorescence microscope equipped with an Olympus DP 26 camera and measured with 'Olympus cellSens Standard' Software.

\subsection{Stomata structure}

The abaxial epidermis was peeled from the leaves using Nail Polish Smear methods based on Liu et al. (2005). In brief, the appropriate plant leaves were selected and coated with nail polish in the abaxial epidermis. The wiping layer was torn using tweezers when the coating layer was slightly connected with the leaf blade after nearly $5 \mathrm{~min}$. The width of the stomata was measured under a research microscope with the help of a precalibrated ocular micrometer. Stomata were counted at random in 20 visual sections on the abaxial epidermis, and final tallies were used to compute their densities. Lengths and widths were measured randomly from 20 stomata on the same specimens using Image J software. Stomata area was counted as length $\times$ width.

\subsection{Gas exchange, chlorophyll a fluorescence and photosynthetic pigments}

Gas exchange and chlorophyll a fluorescence were measured with a portable leaf photosynthesis system (Licor-6400, LI-COR Inc., Lincoln, NE, USA) fitted with a 6400-40 leaf chamber fluorometer (LCF). Two fully expanded upper leaves from one plant were randomly selected in each chamber. The system controlled saturating PPFD at $1200 \mu \mathrm{mol} \mathrm{m} \mathrm{m}^{-2} \mathrm{~s}^{-1}$, block temperature at $30^{\circ} \mathrm{C}$, the $\mathrm{CO}_{2}$ concentration of air entering the leaf at $400 \mu \mathrm{mol} \mathrm{mol}^{-1}$ and the relative humidity at $50-60 \%$. The measurements were conducted during 09:00-12:00 $\mathrm{h}$ in sunny days. In order to minimize possible confounding influences of environmental fluctuations, all measurements were randomized between $\mathrm{O}_{3}$ treatments and among cultivars. The values from light-saturated photosynthesis rate $\left(A_{\text {sat }}\right)$, stomatal conductance $\left(g_{s}\right)$, intercellular $\mathrm{CO}_{2}$ concentration $\left(C_{i}\right)$, transpiration rate $(\operatorname{Tr})$, the actual photochemical efficiency of PSII in the saturated light $\left(F_{v}{ }^{\prime} / F_{m}{ }^{\prime}\right)$, effective quantum yield of PSII photochemistry (PhiPSII) and quenching of photochemical efficiency of PSII $(q P)$ were downloaded from the instruments. Water use efficiency (WUE) was calculated as the ratio of $A_{\text {sat }}$ and $T r$.

Two leaf discs per plant from one plant in each chamber were extracted with $2 \mathrm{ml} \mathrm{95 \%} \mathrm{ethanol} \mathrm{in} \mathrm{the} \mathrm{dark} \mathrm{for} \mathrm{at} \mathrm{least} 72 \mathrm{~h}$ at $4{ }^{\circ} \mathrm{C}$. The absorbance of pigment extracts was measured at 664, 649 and $470 \mathrm{~nm}$. Concentrations of photosynthetic pigments including chlorophyll $a, b$ and carotenoids were calculated according to the specific absorption coefficients provided by Lichtenthaler (1987).

\subsection{Antioxidants}

Three leaves of the third or fourth one from the top per plant were sampled between 12:00 and 14:00 h and quickly wrapped by tinfoil, frozen in liquid nitrogen immediately and stored at $-80^{\circ} \mathrm{C}$ until analysis. Frozen leaf tissues were ground into power in liquid $\mathrm{N}_{2}$ with a mortar and a pestle for the biochemical assay. Malondialdehyde (MDA) content was assessed for estimation of lipid peroxidation by 2-thiobarbituric acid-reactive metabolite (TBA) according to the method of Heath and Packer (1968) and calculated by the equation of $\mathrm{C}_{\mathrm{MDA}}$ ( $\mathrm{m}$ mol $\left.\mathrm{L}^{-1}\right)=6.45 \times\left(\mathrm{OD}_{532}-\mathrm{OD}_{600}\right)-0.56 \times \mathrm{OD}_{450}$ in order to rule out the disturbances from nonspecific $\left(\mathrm{OD}_{600}\right)$ and sugar $\left(\mathrm{OD}_{450}\right)$ absorbance. Total antioxidant capacity (TAC) determinations were conducted following the ferric reducing antioxidant power (FRAP) assay, measuring the combined antioxidant effect of the nonenzymatic defenses, offering a putative index of the ability to resist oxidative damage (Benzie and Strain, 1996), expressed as $\mathrm{Fe}^{3+}$ equivalents (mmol Fe ${ }^{2+} \mathrm{g}^{-1} \mathrm{FM}$ ). Reduced ascorbic acid (ASC) contents were measured by monitoring the changes of absorbance at $265 \mathrm{~nm}$ (extinction coefficient of $14 \mathrm{mM}^{-1} \mathrm{~cm}^{-1}$ ) after addition of ascorbate oxidase (Luwe and Heber, 1995).

For antioxidant enzymes measurement: Samples $(\sim 0.1 \mathrm{~g}$ fresh leaves) were ground in liquid nitrogen and extracted with $2 \mathrm{ml}$ of $50 \mathrm{mM}$ sodium phosphate buffer ( $\mathrm{pH} 7.0$, containing $1 \%$ vinyl pyrrolidone). The samples were centrifuged at $13,000 \mathrm{r} \mathrm{min}^{-1}, 4^{\circ} \mathrm{C}$ for $20 \mathrm{~min}$ and the supernatant was collected. All extracting experiments were carried out in the ice bath. The superoxide dismutase (SOD) activity was determined by estimating its ability of inhibiting the photochemical reduction of nitro blue tetrazolium (NBT) and the absorbance was read at $560 \mathrm{~nm}$. The amount of enzyme that inhibited the $50 \%$ NBT reduction was defined as one unit of SOD activity. The ascorbate peroxidise (APX) activity was assayed by monitoring the change of the absorbance at $290 \mathrm{~nm}$ after the enzyme extract was mixed a $50 \mathrm{mM}$ potassium phosphate buffer ( $\mathrm{PH} 7.0$ ) containing $30 \mathrm{mM}$ ascorbate and $10 \mathrm{mM} \mathrm{H}_{2} \mathrm{O}_{2}$. The enzyme activity was determined by monitoring the change in optical density (OD) at $290 \mathrm{~nm}$ and one unit of APX activity was defined as the decrease of $0.01 \Delta \mathrm{OD}$ per minute. The hydrogen peroxidase (CAT) activity was determined according to the description by Mckee et al. (1997). The change of absorbance at $240 \mathrm{~nm}$ was monitored

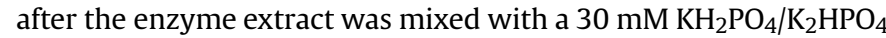
(PH 7.0) containing $10 \mathrm{mM} \mathrm{H}_{2} \mathrm{O}_{2}$. The unit of CAT and POD activity was defined as the decrease and increase of $0.01 \triangle \mathrm{OD}$ per minute at $240 \mathrm{~nm}$ and $470 \mathrm{~nm}$, respectively. All measurements were conducted using spectrophotometric methods.

\subsection{Statistical analysis}

The log-transformed $g_{s}$ and CAT and other all variables in original data passed Shapico-Wilk and Levene's tests for normality and homogeneity of variance, respectively. Then, they were subjected to analysis of variance (ANOVA) with mixed linear model to test the effects of $\mathrm{O}_{3}$, cultivars and their interaction using JMP software (SAS Institute, Cary, NC, USA), in which each OTC represented the statistical unit $(\mathrm{n}=3)$. Turkey's Honestly Significant Difference (HSD) test was applied to indentify significant differences. The 
relationships between cultivar-specific leaf traits (stomata structure, antioxidant defense system and leaf structure) in CF plants and corresponding response variables (AOT40_injury, relative change defined as reduction in $A_{\text {sat }}$ by E- $\mathrm{O}_{3}$ relative to $\mathrm{CF}$ treatment) were assessed by ordinary least square regression using SPSS 20 (SPSS 20, Chicago, IL, USA), in which each cultivar was represented by one data point. $P \leq 0.05$ was considered as statistically significant.

\section{Results}

\subsection{Visible injury}

No visible injury was observed in any of the plants under CF conditions. However, plants exposed to $\mathrm{E}^{-} \mathrm{O}_{3}$ showed typical visible symptoms including reddish stipple, brown spots, and chlorotic and necrotic patches on their leaves (Table 1). At end of the experiment, only three cultivars including 2 nectarines (WC and $R G 29$ ) and 1 white peach (DDT) seedlings did not exhibit visible $\mathrm{O}_{3}$ injury. The most sensitive cultivars were GH2, JY, LH9 and LHC, which displayed visible symptoms on the upper surface of leaves at AOT40 values below $20 \mathrm{ppm} \mathrm{h}$. The cultivars with highest AOT40_injury values ( $>30 \mathrm{ppm}$ h) were $R G 27,76$ and $Z C$ (three nectarines) (Table 1 ). Nearly all of the white peach cultivars except $D D T$ showed more or less visible symptoms when plants were exposed to AOT40 of $50.8 \mathrm{ppm}$ h. The injuries induced by $\mathrm{E}_{-} \mathrm{O}_{3}$ became more severe over time and the leaf senescence was accelerated by $\mathrm{E}_{-} \mathrm{O}_{3}$ in some cultivars.

Among the tested cultivars, three distinct groups with respect to $\mathrm{O}_{3}$ sensitivity could be identified: sensitive cultivars (GH2, JY, LHC and LH9), intermediate cultivars (CJ,W24, LJY, RG27, 76 and ZC) and resistant cultivars ( $R G 29, D D T$ and $W C$ ) based on symptom onset timing.

\subsection{Leaf structure}

$\mathrm{E}-\mathrm{O}_{3}$ significantly reduced abaxial epidemis thickness by $3.06 \%$, but no effects on the thicknesses of adaxial epidemis, palisade parenchyma and spongy parenchyma (Table 2). Cultivars differed significantly on the thicknesses of abaxial epidemis, palisade parenchyma and spongy parenchyma. A significant interaction between $\mathrm{O}_{3}$ and cultivars was found in all four variables $(P<0.05)$ as indicated by the increase in some cultivars like W24, DDT and WC, but the decrease in other cultivars like LHC and RG27 compared with $\mathrm{CF}$. Furthermore, $\mathrm{E}-\mathrm{O}_{3}$ also significantly reduced leaf mass per area (LMA) by $8.49 \%$ across 13 cultivars although there was no significant interaction between $\mathrm{O}_{3}$ and cultivars (Table 2).

\subsection{Stomata structure}

Compared with $\mathrm{CF}$ plants, $\mathrm{E}-\mathrm{O}_{3}$ significantly decreased stomatal area and density of 13 cultivars by $26.0 \%$ and $13.5 \%$, respectively $(P<0.001)$. The declines in stomatal area were significant in cultivars of $G H 2$ and $L H C$, although no significant interaction between $\mathrm{O}_{3}$ and cultivars was found (see Table 3 ).

\subsection{Photosynthesis parameters and water use efficiency}

From Table 4, E- $\mathrm{O}_{3}$ significantly reduced $A_{\text {sat }}$ by $39.9 \%$ across all cultivars, especially for white peach $\mathrm{GH} 2(-46.1 \%), J Y(-52.4 \%)$ and LH9 (-66.3\%) showing the $\mathrm{O}_{3}$ symptoms earlier, but the interaction between $\mathrm{O}_{3}$ and cultivars was close to significant $(P=0.08)$. E- $\mathrm{O}_{3}$ significantly increased $C_{i}$ by $10.6 \%$, reduced WUE by $29.4 \%$, but effect on $g_{s}$ was close to significant $(P=0.087)$.

\subsection{Chlorophyll a fluorescence}

E- $\mathrm{O}_{3}$ significantly reduced $F_{v}{ }^{\prime} / F_{m}{ }^{\prime}$, PhiPSII and $q P$ by $10.8 \%, 30.3 \%$ and $22.3 \%$ across all cultivars, respectively, as compared to those grown in CF chambers (Table 5). Although no significant interaction between $\mathrm{O}_{3}$ and cultivars was found, $\mathrm{E}-\mathrm{O}_{3}$ reduced $F_{v}{ }^{\prime} / F_{m}$ ' among 13 cultivars in a large variation from $5.0 \%$ to $23.3 \%$, PhiPSII from 5.3 to $46.3 \%$ and $q P$ from 3.05 to $36.2 \%$.

\subsection{Photosynthetic pigment content}

Compared to $\mathrm{CF}, \mathrm{E}_{-} \mathrm{O}_{3}$ significantly reduced chlorophyll $a, b, a+b$ and carotenoid contents by $21.3 \%, 20.9 \%, 19.4 \%$ and $19.7 \%$ across 13 cultivars, respectively. However, no interaction between $\mathrm{O}_{3}$ and cultivars was found for all of these photosynthetic pigment variables (Table 6).

\subsection{Antioxidant system and lipid peroxidation}

E- $\mathrm{O}_{3}$ significantly increased the activities of SOD and CAT by $16.2 \%$ and $59.3 \%$, respectively, but not on APX across 13 cultivars (Table 7). However, no significant interaction between $\mathrm{O}_{3}$ and cultivars was observed. Moreover, there was no significant

Table 1

AOT40 at the initial visible $\mathrm{O}_{3}$ symptom onset and the description of the visible symptoms in 10 cultivars of peach seedlings exposed to elevated ozone (E-O $\mathrm{O}_{3}$ ).

\begin{tabular}{|c|c|c|c|c|}
\hline Cultivars & $\begin{array}{l}\text { White peach/ } \\
\text { nectarines }\end{array}$ & $\begin{array}{l}\text { Symptom onset date (days } \\
\text { after fumigation) }\end{array}$ & $\begin{array}{l}\text { AOT40 } \\
(\text { ppm.h) }\end{array}$ & Description of symptoms \\
\hline GH2 & white peach & 15 & 13.6 & $\begin{array}{l}\text { Necrotic spots appeared at the edges of adaxial surface of fully expanded leaves. For serious-injuried } \\
\text { leaves, stippling became brown. Leaf senescence was accelerated }\end{array}$ \\
\hline$J Y$ & white peach & 19 & 15.4 & Yellow reddish interveinal stippling on upper surface and accelerated leaf sennescense \\
\hline LH9 & white peach & 25 & 17.1 & Brown stippling on the upper surface of the leaf, finally coalescing to form large brown patches \\
\hline LHC & white peach & 29 & 19.7 & Light brown interveinal stippling and also finally become dark purple stippling \\
\hline W24 & white peach & 34 & 22.3 & $\begin{array}{l}\text { Brown stippling on the upper surface of the leaf, finally coalescing to form large brown patches. Stippling } \\
\text { more abundant in older leaves }\end{array}$ \\
\hline$C J$ & white peach & 39 & 25.9 & $\begin{array}{l}\text { Chlorosis firstly appeared in fully developed leaves and then leaves turned yellow with pale white stipple } \\
\text { widespread on the surface of leaves }\end{array}$ \\
\hline$L J Y$ & nectarine & 48 & 29.4 & $\begin{array}{l}\text { Necrotic spots appeared at the edges of adaxial surface of fully expanded leaves, In very affected leaves, } \\
\text { stippling becoming brown }\end{array}$ \\
\hline RG27 & nectarine & 51 & 30.6 & Light brown interveinal stippling and also finally become dark purple stippling \\
\hline 76 & nectarine & 60 & 35.5 & Leaf yellowing associated with accelerated senescence \\
\hline ZC & nectarine & 66 & 44.1 & No visible symptoms occurred in developed leaves, but the expanding leaves showed curing \\
\hline RG29 & nectarine & - & - & - \\
\hline DDT & white peach & - & - & - \\
\hline WC & nectarine & - & - & - \\
\hline
\end{tabular}


Table 2

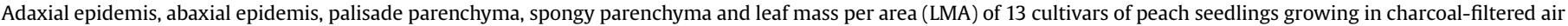
$(\mathrm{CF})$ and elevated $\left[\mathrm{O}_{3}\right]\left(\mathrm{E}-\mathrm{O}_{3}\right)$. Data are shown as Mean $\pm \mathrm{SE}(\mathrm{n}=3)$; different letters indicate statistical differences (Turkey's test, $\left.P<0.05\right)$.

\begin{tabular}{|c|c|c|c|c|c|c|c|c|c|c|}
\hline \multirow[t]{2}{*}{ Cultivars } & \multicolumn{2}{|c|}{$\begin{array}{l}\text { adaxial epidemis } \\
\text { thickness }(\mu \mathrm{m})\end{array}$} & \multicolumn{2}{|c|}{$\begin{array}{l}\text { abaxial epidemis thickness } \\
(\mu \mathrm{m})\end{array}$} & \multicolumn{2}{|c|}{$\begin{array}{l}\text { Palisade parenchyma } \\
\text { thickness }(\mu \mathrm{m})\end{array}$} & \multicolumn{2}{|c|}{$\begin{array}{l}\text { Spongy parenchyma thickness } \\
(\mu \mathrm{m})\end{array}$} & \multicolumn{2}{|c|}{ LMA $\left(\mathrm{g} \mathrm{m}^{-2} \mathrm{DM}\right)$} \\
\hline & $\mathrm{CF}$ & $\mathrm{E}-\mathrm{O}_{3}$ & $\mathrm{CF}$ & $\mathrm{E}-\mathrm{O}_{3}$ & $\mathrm{CF}$ & $\mathrm{E}-\mathrm{O}_{3}$ & $\mathrm{CF}$ & $\mathrm{E}-\mathrm{O}_{3}$ & $\mathrm{CF}$ & $\mathrm{E}-\mathrm{O}_{3}$ \\
\hline GH2 & $9.29 \pm 0.65$ & $9.76 \pm 0.41$ & $7.46 \pm 0.20 a-d$ & $7.25 \pm 0.34 c d$ & $33.7 \pm 1.95 \mathrm{ab}$ & $34.2 \pm 2.40 \mathrm{ab}$ & $37.9 \pm 0.63$ cde & $38.8 \pm 1.30$ cde & $103 \pm 6.23 a$ & $89.1 \pm 0.78 a$ \\
\hline$J Y$ & $9.89 \pm 0.16$ & $9.27 \pm 0.50$ & $7.41 \pm 0.29 a-d$ & $7.39 \pm 0.13 a-d$ & $34.8 \pm 1.08 \mathrm{ab}$ & $37.2 \pm 0.79 a b$ & $40.0 \pm 0.52 a-e$ & $45.6 \pm 0.98 \mathrm{abc}$ & $86.6 \pm 4.10 a$ & $91.7 \pm 1.19 a$ \\
\hline LH9 & $9.02 \pm 0.24$ & $10.2 \pm 0.10$ & $7.52 \pm 0.31 \mathrm{a}-\mathrm{d}$ & $7.68 \pm 0.21 a-d$ & $35.8 \pm 1.19 a b$ & $36.8 \pm 2.32 \mathrm{ab}$ & $41.9 \pm 0.27 a-e$ & $40.3 \pm 1.92 a-e$ & $91.9 \pm 6.70 a$ & $104 \pm 2.63 a$ \\
\hline$L H C$ & $9.58 \pm 0.17$ & $9.48 \pm 0.14$ & $7.46 \pm 0.09 a-d$ & $7.32 \pm 0.04 \mathrm{bcd}$ & $42.4 \pm 4.05 a$ & $35.4 \pm 0.86 a b$ & $44 \pm 1.65 a-d$ & $39 \pm 1.60 b-e$ & $109 \pm 3.38 a$ & $84.4 \pm 2.97 a$ \\
\hline W24 & $10.1 \pm 0.43$ & $10.3 \pm 0.33$ & $7.59 \pm 0.18 a-d$ & $8.38 \pm 0.26 a$ & $33.3 \pm 2.99 \mathrm{ab}$ & $39.4 \pm 2.28 \mathrm{ab}$ & $38.3 \pm 0.75$ cde & $46.7 \pm 0.97 a b$ & $94.9 \pm 3.64 a$ & $108 \pm 4.52 \mathrm{a}$ \\
\hline$C J$ & $9.94 \pm 0.24$ & $9.89 \pm 0.11$ & $7.55 \pm 0.13 a-d$ & $8.35 \pm 0.11 \mathrm{ab}$ & $36.0 \pm 0.91 \mathrm{ab}$ & $32.3 \pm 0.65 a b$ & $41.1 \pm 0.35 a-e$ & $39 \pm 1.46 \mathrm{~b}-\mathrm{e}$ & $109 \pm 1.85 a$ & $95.7 \pm 3.56 a$ \\
\hline$L J Y$ & $9.64 \pm 0.17$ & $9.86 \pm 0.13$ & $7.68 \pm 0.14 a-d$ & $7.65 \pm 0.21 \mathrm{a}-\mathrm{d}$ & $30.3 \pm 0.62 b$ & $35.0 \pm 1.08 \mathrm{ab}$ & $37.3 \pm 1.40 \mathrm{de}$ & $38.4 \pm 0.74$ cde & $101 \pm 5.37 a$ & $84.1 \pm 3.83 a$ \\
\hline$R G 27$ & $9.65 \pm 0.01$ & $9.00 \pm 0.18$ & $7.43 \pm 0.04 a-d$ & $7.16 \pm 0.11 \mathrm{~cd}$ & $33.9 \pm 1.40 \mathrm{ab}$ & $32.5 \pm 0.82 \mathrm{ab}$ & $39.8 \pm 1.47 a-e$ & $38.3 \pm 1.83 \mathrm{cde}$ & $112 \pm 1.95 a$ & $90.5 \pm 2.91 a$ \\
\hline 76 & $9.59 \pm 0.21$ & $9.15 \pm 0.26$ & $7.75 \pm 0.09 a-d$ & $7.89 \pm 0.14 a-d$ & $36.4 \pm 1.64 a b$ & $31.9 \pm 0.11 \mathrm{ab}$ & $47.6 \pm 2.26 a$ & $40.1 \pm 1.02 \mathrm{a}-\mathrm{e}$ & $110 \pm 2.83 a$ & $95.3 \pm 1.58 a$ \\
\hline$Z C$ & $10.2 \pm 0.31$ & $9.41 \pm 0.15$ & $7.64 \pm 0.09 a-d$ & $7.54 \pm 0.16 a-d$ & $29.4 \pm 0.38 b$ & $34.1 \pm 0.26 a b$ & $35.5 \pm 2.29 \mathrm{e}$ & $39.5 \pm 0.60 b-e$ & $117 \pm 5.03 a$ & $106 \pm 4.51 \mathrm{a}$ \\
\hline$D D T$ & $9.62 \pm 0.28$ & $9.57 \pm 0.15$ & $7.35 \pm 0.04 a-d$ & $8.12 \pm 0.29 a b c$ & $35.5 \pm 0.81 \mathrm{ab}$ & $38.2 \pm 3.44 a b$ & $41.4 \pm 0.17 a-e$ & $42.9 \pm 1.79 a-e$ & $106 \pm 2.90 \mathrm{a}$ & $92.9 \pm 3.22 \mathrm{a}$ \\
\hline$R G 29$ & $9.19 \pm 0.30$ & $9.92 \pm 0.09$ & $7.07 \pm 0.06 \mathrm{~d}$ & $7.56 \pm 0.08 a-d$ & $33.9 \pm 0.53 a b$ & $32.4 \pm 0.49 a b$ & $38.8 \pm 1.70$ cde & $42.3 \pm 2.11 \mathrm{a}-\mathrm{e}$ & $109 \pm 4.31 \mathrm{a}$ & $101 \pm 4.04 a$ \\
\hline$W C$ & $9.61 \pm 0.23$ & $9.25 \pm 0.04$ & $7.35 \pm 0.33 a-d$ & $7.94 \pm 0.26 a-d$ & $38.4 \pm 2.04 a b$ & $41.3 \pm 4.70 a$ & $40.6 \pm 2.21 \mathrm{a}-\mathrm{e}$ & $40.7 \pm 1.31 \mathrm{a}-\mathrm{e}$ & $104 \pm 3.92 a$ & $95.5 \pm 1.28 \mathrm{a}$ \\
\hline \multicolumn{11}{|l|}{ ANOVA } \\
\hline $\mathrm{O}_{3}$ & 0.812 & & 0.003 & & 0.483 & & 0.317 & & 0.010 & \\
\hline Cultivars & 0.125 & & 0.003 & & 0.002 & & 0.0003 & & 0.570 & \\
\hline $\mathrm{O}_{3}{ }^{*}$ Cultivars & 0.022 & & 0.025 & & 0.034 & & $<0.0001$ & & 0.455 & \\
\hline
\end{tabular}

Table 3

Stomatal area and density of 13 cultivars of peach seedlings growing in charcoalfiltered air $(\mathrm{CF})$ and elevated $\left[\mathrm{O}_{3}\right]\left(\mathrm{E}-\mathrm{O}_{3}\right)$. Data are shown as Mean $\pm \mathrm{SE}(\mathrm{n}=3)$; different letters indicate statistical differences (Turkey's test, $P<0.05$ ).

\begin{tabular}{|c|c|c|c|c|}
\hline \multirow[t]{2}{*}{ Cultivars } & \multicolumn{2}{|c|}{ Stomatal area $\left(\mu \mathrm{m}^{2}\right)$} & \multicolumn{2}{|c|}{ Stomatal density $\left(\mathrm{mm}^{-2}\right)$} \\
\hline & $\mathrm{CF}$ & $\mathrm{E}-\mathrm{O}_{3}$ & $\mathrm{CF}$ & $\mathrm{E}-\mathrm{O}_{3}$ \\
\hline GH2 & $1209 \pm 106 a b$ & $651 \pm 90.6 c$ & $303 \pm 10.1 a b$ & $248 \pm 12.0 \mathrm{ab}$ \\
\hline$J Y$ & $1023 \pm 119 a b c$ & $749 \pm 42.4 a b c$ & $285 \pm 21.8 a b$ & $323 \pm 8.80 a$ \\
\hline LH9 & $916 \pm 191 a b c$ & $778 \pm 103 a b c$ & $278 \pm 40.9 \mathrm{ab}$ & $222 \pm 31.1 b$ \\
\hline$L H C$ & $1273 \pm 199 a$ & $727 \pm 73.3 b c$ & $268 \pm 7.30 \mathrm{ab}$ & $249 \pm 16.0 a b$ \\
\hline W24 & $887 \pm 87.3 a b c$ & $867 \pm 67.5 a b c$ & $288 \pm 14.2 \mathrm{ab}$ & $243 \pm 15.9 a b$ \\
\hline$C J$ & $1120 \pm 71.7 a b c$ & $813 \pm 62.1 \mathrm{abc}$ & $297 \pm 6.00 \mathrm{ab}$ & $258 \pm 15.9 a b$ \\
\hline$L J Y$ & $951 \pm 62.2 \mathrm{abc}$ & $887 \pm 105 a b c$ & $325 \pm 20.2 a$ & $237 \pm 18.3 a b$ \\
\hline$R G 27$ & $1280 \pm 192 a$ & $894 \pm 94.3 a b c$ & $280 \pm 20.8 \mathrm{ab}$ & $272 \pm 10.9 \mathrm{ab}$ \\
\hline 76 & $1022 \pm 131 a b c$ & $684 \pm 41.1 b c$ & $288 \pm 16.4 \mathrm{ab}$ & $246 \pm 7.30 a b$ \\
\hline$Z C$ & $1128 \pm 72.2 \mathrm{abc}$ & $855 \pm 59.3 a b c$ & $290 \pm 5.80 \mathrm{ab}$ & $249 \pm 14.7 a b$ \\
\hline$D D T$ & $966 \pm 29.5 a b c$ & $711 \pm 26.2 b c$ & $303 \pm 23.5 \mathrm{ab}$ & $257 \pm 8.80 a b$ \\
\hline$R G 29$ & $1082 \pm 54.9 \mathrm{abc}$ & $821 \pm 107 a b c$ & $298 \pm 30.0 \mathrm{ab}$ & $228 \pm 15.9 a b$ \\
\hline$W C$ & $903 \pm 31.2 \mathrm{abc}$ & $747 \pm 18.3 a b c$ & $288 \pm 24.2 b$ & $251 \pm 5.00 a b$ \\
\hline ANOVA & & & & \\
\hline $\mathrm{O}_{3}$ & \multicolumn{2}{|l|}{$<0.0001$} & \multicolumn{2}{|l|}{$<0.0001$} \\
\hline Cultivars & \multicolumn{2}{|l|}{0.299} & \multicolumn{2}{|l|}{0.452} \\
\hline $\mathrm{O}_{3}{ }^{*}$ Cultivars & \multicolumn{2}{|l|}{0.224} & \multicolumn{2}{|l|}{0.191} \\
\hline
\end{tabular}

difference among cultivars in the activities of APX and SOD across two $\mathrm{O}_{3}$ treatments, but the very close significant difference in CAT activity was found (Table 7 ).

E- $\mathrm{O}_{3}$ significantly decreased ASC content by $24.0 \%$ across 13 cultivars (Table 8). However, a significant interaction between $\mathrm{O}_{3}$ and cultivars was found. The reduction of ASC by E- $\mathrm{O}_{3}$ in ten cultivars ranged from $7.03 \%$ to $66.5 \%$ except $L H 9(+49.7 \%), Z C(+26.7 \%)$ and $D D T(+8.0 \%)$. On the other hand, $\mathrm{E}^{-} \mathrm{O}_{3}$ significantly increased TAC content by $23.5 \%$ across 13 cultivars despite no significant interaction. $\mathrm{E}_{-} \mathrm{O}_{3}$ significantly increased MDA contents by $30.9 \%$ across 13 cultivars, but no interaction between $\mathrm{O}_{3}$ and cultivars was found although the largest increase in GH2 cultivar was $92.0 \%$ (Table 8).

\subsection{Correlations between variables}

As shown in Table 9, LMA in CF plants was positively correlated with AOT40_injury and negatively correlated with reductions in $A_{\text {sat }}$ induced by E-O $\mathrm{O}_{3}$. However, neither stomatal parameters (SA, SD and $g_{s}$ ) nor antioxidants (TAC, ASC and A-TAC, A-ASC) were found to be significantly correlated with these two response parameters. For antioxidant enzymes, SOD was negatively correlated with reductions in $A_{\text {sat }}$. A-SOD was positively correlated with AOT40_injury, and negatively correlated with reductions in $A_{\text {sat }}$ APX was positively correlated with reductions in $A_{\text {sat }}$ but A-APX was positively correlated with AOT40_injury. There were no significant correlations between the two response parameters and CAT or ACAT. $g_{s} /$ LMA was negatively correlated with reductions in $A_{s a t}$.

\section{Discussion}

\subsection{Effects of $\mathrm{E}_{-} \mathrm{O}_{3}$ among peach cultivars}

Besides foliar symptoms, $\mathrm{E}-\mathrm{O}_{3}$ also induced serious effects on the thickness of the abaxial epidemis, but not on palisade parenchyma and spongy parenchyma in leaves of peach seedlings. In addition, leaf senescence was significantly accelerated by $\mathrm{E}-\mathrm{O}_{3}$ as indicated by the significant decrease in chlorophyll contents and increase in MDA contents. Furthermore, $\mathrm{E}-\mathrm{O}_{3}$ induced the change in chlorophyll and MDA contents in white peach cultivars $(-28.2 \%$ and $+42.1 \%$, respectively) higher than those in nectarine cultivars ( $-8.15 \%$ and $+19.4 \%$, respectively), suggesting that white peach cultivars are more sensitive to $\mathrm{O}_{3}$ than nectarine cultivars.

As a gate $\mathrm{O}_{3}$ entering into plants, stomata react to changing environmental parameters by opening or closing. In this study, no significant differences in stomatal area and density were found among 13 peach cultivars under $\mathrm{CF}$ treatments. Stomatal area and density were significantly increased by $\mathrm{E}^{-\mathrm{O}_{3}}$ in different magnitudes $(P<0.001)$, which are fully different from those in tobacco (Saitanis and Karandinos, 2002) and birch (Betula pendula Roth.) (Frey et al., 1996). The different results may be attributed to plant properties and/or $\mathrm{O}_{3}$ levels.

In this study, $\mathrm{E}_{-} \mathrm{O}_{3}$ induced a large amount of reduction in $A_{s a t}$ in most cultivars with an uncoupling of the relationship between $A_{\text {sat }}$ and $g_{s}$. The reductions in $A_{s a t}$ in white peach cultivars like GH2, JY and $L H 9$ were higher than nectarine cultivars like $Z C, R G 29$ and $W C$, suggesting that white peach cultivars was more severely damaged by $\mathrm{E}-\mathrm{O}_{3}$ than nectarine cultivars. However, the effect of $\mathrm{E}-\mathrm{O}_{3}$ on $g_{s}$ was not consistent among cultivars as indicated by an increase in some cultivars and a decrease in others (Table 4 ), suggesting that $g_{s}$ may not contribute to the significant difference among cultivars in response to $\mathrm{E}_{-} \mathrm{O}_{3}$. Moreover, $\mathrm{O}_{3}$-induced an increase in $C_{i}$, 
Table 4

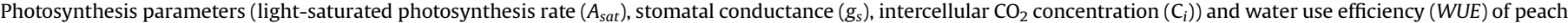

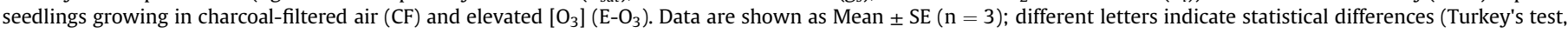
$P<0.05)$.

\begin{tabular}{|c|c|c|c|c|c|c|c|c|}
\hline \multirow[t]{2}{*}{ Cultivars } & \multicolumn{2}{|c|}{$A_{\mathrm{sat}}\left(\mu \mathrm{mol} \mathrm{CO} \mathrm{m}^{-2} \mathrm{~s}^{-1}\right)$} & \multicolumn{2}{|c|}{$g_{s}\left(\mathrm{~mol} \mathrm{H}_{2} \mathrm{O} \mathrm{m}^{-2} \mathrm{~s}^{-1}\right)$} & \multicolumn{2}{|c|}{$\mathrm{Ci}\left(\mu \mathrm{mol} \mathrm{mol}{ }^{-1}\right)$} & \multicolumn{2}{|c|}{ WUE $\left(\mu \mathrm{mol} \mathrm{CO} \mathrm{mmol}^{-1} \mathrm{H}_{2} \mathrm{O}\right)$} \\
\hline & $\mathrm{CF}$ & $\mathrm{E}-\mathrm{O}_{3}$ & $\mathrm{CF}$ & $\mathrm{E}-\mathrm{O}_{3}$ & $\mathrm{CF}$ & $\mathrm{E}-\mathrm{O}_{3}$ & $\mathrm{CF}$ & $\mathrm{E}-\mathrm{O}_{3}$ \\
\hline GH2 & $11.5 \pm 1.18 \mathrm{abc}$ & $6.20 \pm 0.85 \mathrm{~d}-\mathrm{g}$ & $0.10 \pm 0.01$ & $0.17 \pm 0.01$ & $226 \pm 19.7 a$ & $309 \pm 5.73 a$ & $8.83 \pm 0.86 a$ & $4.02 \pm 0.18 \mathrm{ab}$ \\
\hline$J Y$ & $11.7 \pm 1.67 a b$ & $5.60 \pm 1.19 \mathrm{efg}$ & $0.24 \pm 0.04$ & $0.27 \pm 0.07$ & $290 \pm 23.1 a$ & $340 \pm 9.08 a$ & $5.2 \pm 0.77 \mathrm{ab}$ & $2.30 \pm 0.21 b$ \\
\hline LH9 & $11.9 \pm 0.98 a b$ & $4.00 \pm 0.51 \mathrm{~g}$ & $0.11 \pm 0.004$ & $0.12 \pm 0.04$ & $196 \pm 4.29 a$ & $304 \pm 17.4 a$ & $7.02 \pm 0.18 a b$ & $4.05 \pm 0.50 \mathrm{ab}$ \\
\hline$L H C$ & $10.2 \pm 0.04 a-e$ & $7.40 \pm 0.33 b-g$ & $0.31 \pm 0.08$ & $0.24 \pm 0.06$ & $319 \pm 13.1 \mathrm{a}$ & $312 \pm 18.6 a$ & $3.77 \pm 0.31 \mathrm{ab}$ & $3.60 \pm 0.69 a b$ \\
\hline W24 & $11.4 \pm 1.15 a b c$ & $6.90 \pm 0.57 \mathrm{c}-\mathrm{g}$ & $0.30 \pm 0.04$ & $0.14 \pm 0.01$ & $318 \pm 8.71 a$ & $301 \pm 13.1 a$ & $3.94 \pm 0.32 \mathrm{ab}$ & $4.31 \pm 0.19 \mathrm{ab}$ \\
\hline$C J$ & $11.4 \pm 0.59 a b c$ & $7.50 \pm 1.08 \mathrm{~b}-\mathrm{g}$ & $0.23 \pm 0.04$ & $0.19 \pm 0.05$ & $269 \pm 31.1 a$ & $290 \pm 23.8 a$ & $6.11 \pm 0.86 a b$ & $4.57 \pm 0.84 a b$ \\
\hline$L J Y$ & $9.8 \pm 0.75 a-f$ & $5.30 \pm 0.49 f g$ & $0.15 \pm 0.02$ & $0.15 \pm 0.04$ & $271 \pm 16.0 a$ & $301 \pm 18.5 a$ & $6.37 \pm 0.56 a b$ & $3.77 \pm 0.43 a b$ \\
\hline$R G 27$ & $11.4 \pm 0.93 \mathrm{abc}$ & $6.70 \pm 0.51 \mathrm{~d}-\mathrm{g}$ & $0.24 \pm 0.04$ & $0.19 \pm 0.03$ & $290 \pm 19.8 a$ & $311 \pm 17.6 a$ & $5.42 \pm 0.71 \mathrm{ab}$ & $3.61 \pm 0.48 \mathrm{ab}$ \\
\hline 76 & $13.1 \pm 0.50 a$ & $7.60 \pm 0.28 b-g$ & $0.31 \pm 0.09$ & $0.21 \pm 0.01$ & $297 \pm 20.7 a$ & $315 \pm 0.62 a$ & $4.61 \pm 0.29 a b$ & $3.69 \pm 0.36 a b$ \\
\hline$Z C$ & $10.8 \pm 0.92 a-d$ & $7.40 \pm 0.74 \mathrm{~b}-\mathrm{g}$ & $0.29 \pm 0.03$ & $0.27 \pm 0.05$ & $317 \pm 6.61 a$ & $330 \pm 10.9 a$ & $4.05 \pm 0.50 \mathrm{ab}$ & $2.83 \pm 0.30 \mathrm{~b}$ \\
\hline$D D T$ & $9.70 \pm 1.33 a-f$ & $5.70 \pm 0.50 \mathrm{e}-\mathrm{g}$ & $0.31 \pm 0.08$ & $0.18 \pm 0.05$ & $262 \pm 48.5 a$ & $306 \pm 21.3 a$ & $6.19 \pm 1.46 a b$ & $4.1 \pm 0.93 a b$ \\
\hline$R G 29$ & $9.80 \pm 0.99 a-f$ & $7.60 \pm 0.26 \mathrm{~b}-\mathrm{g}$ & $0.35 \pm 0.09$ & $0.17 \pm 0.02$ & $310 \pm 17.9 a$ & $315 \pm 16.0 a$ & $3.97 \pm 0.27 \mathrm{ab}$ & $3.77 \pm 0.69 \mathrm{ab}$ \\
\hline$W C$ & $10.7 \pm 1.07 a-d$ & $8.40 \pm 0.32 b-g$ & $0.33 \pm 0.09$ & $0.17 \pm 0.03$ & $288 \pm 20.9 a$ & $306 \pm 10.1 a$ & $4.98 \pm 0.17 a b$ & $5.15 \pm 0.64 a b$ \\
\hline \multicolumn{9}{|l|}{ ANOVA } \\
\hline $\mathrm{O}_{3}$ & $<0.0001$ & & 0.087 & & 0.026 & & $<0.001$ & \\
\hline Cultivars & 0.113 & & 0.308 & & 0.609 & & 0.194 & \\
\hline $\mathrm{O}_{3}{ }^{*}$ Cultivars & 0.080 & & 0.977 & & 0.867 & & 0.456 & \\
\hline
\end{tabular}

Table 5

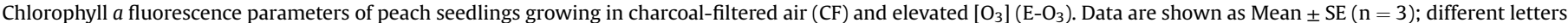
indicate statistical differences (Turkey's test, $P<0.05$ ).

\begin{tabular}{|c|c|c|c|c|c|c|}
\hline \multirow[t]{2}{*}{ Cultivars } & \multicolumn{2}{|l|}{$F v^{\prime} \mid F m^{\prime}$} & \multicolumn{2}{|l|}{ PhiPS2 } & \multicolumn{2}{|l|}{$q P$} \\
\hline & CF & $\mathrm{E}-\mathrm{O}_{3}$ & $\mathrm{CF}$ & $\mathrm{E}-\mathrm{O}_{3}$ & CF & $\mathrm{E}-\mathrm{O}_{3}$ \\
\hline GH2 & $0.53 \pm 0.03 a$ & $0.42 \pm 0.01 a$ & $0.13 \pm 0.01 a-d$ & $0.11 \pm 0.01 \mathrm{a}-\mathrm{d}$ & $0.24 \pm 0.004 a$ & $0.259 \pm 0.014 a$ \\
\hline$J Y$ & $0.52 \pm 0.02 a$ & $0.42 \pm 0.04 a$ & $0.15 \pm 0.01 \mathrm{abc}$ & $0.08 \pm 0.01 d$ & $0.29 \pm 0.02 \mathrm{a}$ & $0.191 \pm 0.018 a$ \\
\hline LH9 & $0.47 \pm 0.02 a$ & $0.43 \pm 0.05 a$ & $0.15 \pm 0.01 a-d$ & $0.09 \pm 0.01 \mathrm{bcd}$ & $0.32 \pm 0.03 a$ & $0.21 \pm 0.01 \mathrm{a}$ \\
\hline$L H C$ & $0.50 \pm 0.04 a$ & $0.47 \pm 0.03 a$ & $0.14 \pm 0.003 a-d$ & $0.08 \pm 0.01 \mathrm{bcd}$ & $0.30 \pm 0.03 a$ & $0.18 \pm 0.01 a$ \\
\hline W24 & $0.55 \pm 0.04 a$ & $0.51 \pm 0.02 a$ & $0.16 \pm 0.01 a$ & $0.11 \pm 0.01 a-d$ & $0.31 \pm 0.04 a$ & $0.22 \pm 0.02 a$ \\
\hline$C J$ & $0.59 \pm 0.03 a$ & $0.56 \pm 0.04 a$ & $0.12 \pm 0.004 a-d$ & $0.12 \pm 0.002 a-d$ & $0.21 \pm 0.02 a$ & $0.21 \pm 0.02 a$ \\
\hline$L J Y$ & $0.45 \pm 0.04 a$ & $0.38 \pm 0.03 a$ & $0.13 \pm 0.006 a-d$ & $0.11 \pm 0.01 a-d$ & $0.29 \pm 0.03 a$ & $0.28 \pm 0.02 a$ \\
\hline$R G 27$ & $0.53 \pm 0.03 a$ & $0.45 \pm 0.03 a$ & $0.15 \pm 0.004 a-d$ & $0.10 \pm 0.01 a-d$ & $0.28 \pm 0.02 a$ & $0.24 \pm 0.03 a$ \\
\hline 76 & $0.49 \pm 0.04 a$ & $0.46 \pm 0.01 a$ & $0.13 \pm 0.01 a-d$ & $0.08 \pm 0.002 \mathrm{bcd}$ & $0.27 \pm 0.03 a$ & $0.18 \pm 0.01 a$ \\
\hline$Z C$ & $0.46 \pm 0.06 a$ & $0.48 \pm 0.02 a$ & $0.14 \pm 0.01 a-d$ & $0.10 \pm 0.002 a-d$ & $0.31 \pm 0.03 a$ & $0.22 \pm 0.01 a$ \\
\hline DDT & $0.47 \pm 0.06 a$ & $0.36 \pm 0.02 a$ & $0.13 \pm 0.02 a-d$ & $0.08 \pm 0.01 \mathrm{~cd}$ & $0.27 \pm 0.01 a$ & $0.23 \pm 0.02 a$ \\
\hline$R G 29$ & $0.55 \pm 0.03 a$ & $0.49 \pm 0.04 a$ & $0.15 \pm 0.004 a b$ & $0.08 \pm 0.004 b c d$ & $0.27 \pm 0.01 a$ & $0.17 \pm 0.02 a$ \\
\hline$W C$ & $0.54 \pm 0.02 a$ & $0.52 \pm 0.02 a$ & $0.16 \pm 0.003 a$ & $0.13 \pm 0.01 a-d$ & $0.29 \pm 0.01 a$ & $0.24 \pm 0.01 a$ \\
\hline \multicolumn{7}{|l|}{ ANOVA } \\
\hline $\mathrm{O}_{3}$ & 0.016 & & $<0.0001$ & & $<0.0001$ & \\
\hline Cultivars & 0.257 & & 0.105 & & 0.601 & \\
\hline $\mathrm{O}_{3}{ }^{*}$ Cultivars & 0.995 & & 0.283 & & 0.606 & \\
\hline
\end{tabular}

Table 6

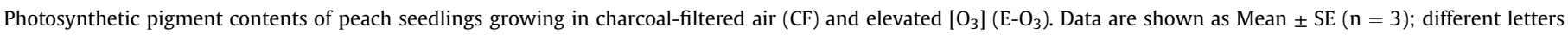
indicate statistical differences (Turkey's test, $P<0.05$ ).

\begin{tabular}{|c|c|c|c|c|c|c|c|c|}
\hline \multirow[t]{2}{*}{ Cultivars } & \multicolumn{2}{|c|}{$\begin{array}{l}\text { Chlorophyll } a \text { content } \\
\left(\times 10 \mathrm{mg} \mathrm{m}^{-2}\right)\end{array}$} & \multicolumn{2}{|c|}{$\begin{array}{l}\text { Chlorophyll } b \text { content } \\
\left(\times 10 \mathrm{mg} \mathrm{m}^{-2}\right)\end{array}$} & \multicolumn{2}{|c|}{$\begin{array}{l}\text { Carotenoids content } \\
\left(\times 10 \mathrm{mg} \mathrm{m}^{-2}\right)\end{array}$} & \multicolumn{2}{|c|}{$\begin{array}{l}\text { Chlorophyll } a+b \text { content } \\
\left(\times 10 \mathrm{mg} \mathrm{m}^{-2}\right)\end{array}$} \\
\hline & $\mathrm{CF}$ & $\mathrm{E}-\mathrm{O}_{3}$ & $\mathrm{CF}$ & $\mathrm{E}-\mathrm{O}_{3}$ & $\mathrm{CF}$ & $\mathrm{E}-\mathrm{O}_{3}$ & $\mathrm{CF}$ & $\mathrm{E}-\mathrm{O}_{3}$ \\
\hline GH2 & $22.5 \pm 6.43 \mathrm{ab}$ & $15.5 \pm 1.56 \mathrm{ab}$ & $7.78 \pm 4.03$ & $6.01 \pm 0.76$ & $8.6 \pm 0.77 b c$ & $6.10 \pm 0.50 b c$ & $30.3 \pm 10.4 a b$ & $21.5 \pm 2.32 \mathrm{ab}$ \\
\hline$J Y$ & $18.3 \pm 2.49 \mathrm{ab}$ & $6.30 \pm 2.78 b$ & $8.84 \pm 0.52$ & $1.79 \pm 1.36$ & $8.97 \pm 1.65 b c$ & $4.26 \pm 0.33 c$ & $19.0 \pm 10.5 \mathrm{ab}$ & $8.13 \pm 4.14 b$ \\
\hline LH9 & $18.7 \pm 2.11 \mathrm{ab}$ & $19.3 \pm 3.64 a b$ & $8.29 \pm 1.20$ & $7.57 \pm 1.26$ & $6.95 \pm 0.98 b c$ & $7.50 \pm 1.47 \mathrm{bc}$ & $27.0 \pm 3.23 \mathrm{ab}$ & $26.9 \pm 4.90 \mathrm{ab}$ \\
\hline$L H C$ & $20.0 \pm 3.11 \mathrm{ab}$ & $13.2 \pm 6.97 \mathrm{ab}$ & $7.41 \pm 2.06$ & $3.75 \pm 3.33$ & $8.01 \pm 0.71 b c$ & $5.84 \pm 1.58 b c$ & $27.4 \pm 5.07 a b$ & $17.0 \pm 10.2 \mathrm{ab}$ \\
\hline W24 & $24.5 \pm 3.33 \mathrm{ab}$ & $17.3 \pm 5.17 \mathrm{ab}$ & $7.48 \pm 4.08$ & $6.56 \pm 2.13$ & $9.85 \pm 0.65 b$ & $6.94 \pm 1.46 b c$ & $31.9 \pm 7.22 \mathrm{ab}$ & $23.8 \pm 7.30 \mathrm{ab}$ \\
\hline$C J$ & $27.8 \pm 3.73 a$ & $17.8 \pm 1.39 \mathrm{ab}$ & $12.3 \pm 1.20$ & $7.77 \pm 1.28$ & $19.0 \pm 1.18 a$ & $18.1 \pm 1.19 a$ & $40.1 \pm 4.92 \mathrm{a}$ & $25.6 \pm 2.65 a b$ \\
\hline$L J Y$ & $16.6 \pm 3.01 \mathrm{ab}$ & $11.6 \pm 2.25 \mathrm{ab}$ & $4.83 \pm 3.13$ & $4.02 \pm 1.08$ & $7.05 \pm 0.35 b c$ & $4.03 \pm 0.50 c$ & $21.4 \pm 6.12 \mathrm{ab}$ & $15.6 \pm 3.30 a b$ \\
\hline$R G 27$ & $25.9 \pm 2.66 a$ & $15.8 \pm 1.80 \mathrm{ab}$ & $8.43 \pm 3.32$ & $5.66 \pm 0.93$ & $9.83 \pm 0.69 b$ & $6.39 \pm 1.01 b c$ & $34.4 \pm 5.73 \mathrm{ab}$ & $21.5 \pm 2.72 \mathrm{ab}$ \\
\hline 76 & $21.4 \pm 0.53 \mathrm{ab}$ & $18.7 \pm 1.25 a b$ & $6.34 \pm 2.67$ & $7.24 \pm 0.65$ & $8.52 \pm 1.14 b c$ & $5.87 \pm 0.25 b c$ & $27.8 \pm 2.78 \mathrm{ab}$ & $26.0 \pm 1.90 a b$ \\
\hline$Z C$ & $15.8 \pm 2.10 \mathrm{ab}$ & $22.5 \pm 4.95 \mathrm{ab}$ & $5.07 \pm 2.77$ & $8.81 \pm 2.26$ & $7.39 \pm 0.32 b c$ & $7.18 \pm 1.41 b c$ & $20.8 \pm 4.86 a b$ & $31.3 \pm 7.20 a b$ \\
\hline$D D T$ & $23.6 \pm 2.88 \mathrm{ab}$ & $19.6 \pm 4.02 \mathrm{ab}$ & $9.84 \pm 0.92$ & $7.64 \pm 1.95$ & $8.16 \pm 0.78 b c$ & $6.77 \pm 0.62 b c$ & $33.4 \pm 3.80 \mathrm{ab}$ & $27.3 \pm 5.97 a b$ \\
\hline$R G 29$ & $21.7 \pm 2.03 \mathrm{ab}$ & $21.4 \pm 0.73 \mathrm{ab}$ & $8.95 \pm 0.90$ & $8.72 \pm 0.12$ & $8.10 \pm 0.33 b c$ & $9.19 \pm 0.55 b c$ & $30.7 \pm 2.90 \mathrm{ab}$ & $30.2 \pm 0.78 \mathrm{ab}$ \\
\hline$W C$ & $18.9 \pm 2.28 \mathrm{ab}$ & $17.9 \pm 4.21 \mathrm{ab}$ & $8.44 \pm 0.54$ & $6.76 \pm 1.82$ & $7.46 \pm 0.24 b c$ & $6.45 \pm 1.26 b c$ & $27.4 \pm 2.82 \mathrm{ab}$ & $24.7 \pm 6.03 a b$ \\
\hline \multicolumn{9}{|l|}{ ANOVA } \\
\hline $\mathrm{O}_{3}$ & 0.001 & & 0.053 & & $<0.001$ & & 0.015 & \\
\hline Cultivars & 0.113 & & 0.368 & & $<0.001$ & & 0.099 & \\
\hline $\mathrm{O}_{3}{ }^{*}$ Cultivars & 0.318 & & 0.717 & & 0.144 & & 0.735 & \\
\hline
\end{tabular}


suggesting that the reduction in $A_{s a t}$ by $\mathrm{O}_{3}$ largely attributed to nonstomatal factors, i.e. impaired photosynthetic activity including reduced Rubisco activity, ribulose-1, 5-bisphosphate (RuBP) regeneration, decrease in chlorophyll $a$ fluorescence or pigments (Akhtar et al., 2010; Feng et al., 2016).

Furthermore, the observed declines in $F_{v}{ }^{\prime} / F_{m}{ }^{\prime}$, PhiPSII and $q P$ (Table 5) suggest that $\mathrm{E}-\mathrm{O}_{3}$ increased light energy dissipation of the antenna pigment and caused reduction in the efficiency of excitation energy captured by the open PSII reaction centers (Zhang et al., 2014). The relatively higher decrease in PhiPSII in white peach cultivars like JY, LH9 and LHC indicates that white peach seedlings have a weaker capacity for carbon metabolism and/or a low utilization of ATP and NADPH compared with the nectarine cultivars (Subrahmanyam and Rathore, 2000).

Although $\mathrm{E}_{-} \mathrm{O}_{3}$ reduced the ASC content, with exceptions of $\mathrm{LH} 9$, $Z C$ and $D D T$, the activities of CAT, APX and SOD were significantly increased by $\mathrm{E}-\mathrm{O}_{3}$ compared to $\mathrm{CF}$. It may explain why the TAC content was increased by $\mathrm{E}_{-} \mathrm{O}_{3}$ (Tables 7 and 8). Our results suggest that $\mathrm{E}-\mathrm{O}_{3}$ produced damage to the antioxidant system of the peach seedlings and increased the unbalance between antioxidants and antioxidative enzymes. The damaged activating detoxification and repair mechanisms induced by $\mathrm{E}_{-} \mathrm{O}_{3}$ may finally have negative effects on peach productivity.

\subsection{Possible causes for the different sensitivities to $\mathrm{O}_{3}$ among cultivars}

It has been reported that the $\mathrm{O}_{3}$ sensitivity of plants is linked to $\mathrm{O}_{3}$ flux controlled by stomata (Dizengremel et al., 2009; Paoletti, 2006) and antioxidant capacity determined by antioxidant pools and enzymes (Feng et al., 2010; Li et al., 2016; Wang et al., 2015). In this study, two $\mathrm{O}_{3}$ response variables were used: AOT40_injury and the changes in $A_{\text {sat }}$. AOT40_injury has been frequently considered as an indicator of $\mathrm{O}_{3}$ sensitivity (Calatayud et al., 2007; Li et al., 2016; Zhang et al., 2012). The $\mathrm{O}_{3}$-induced reduction in $A_{\text {sat }}$ is a functional response variable related to plant primary production that has been commonly used to assess the $\mathrm{O}_{3}$ sensitivity among species (Li et al., 2016). Moreover, we found that the AOT40_injury was almost closely significantly linked to negative effects of $\mathrm{O}_{3}$ on photosynthesis $(P=0.091)$.

In the current experiment, we try to find the relationship between patterns of response and leaf properties associated with $\mathrm{O}_{3}$ sensitivity among cultivars in one species. We found that the $\mathrm{O}_{3}$ sensitivity among cultivars was strongly linked to LMA (Table 9). Bussotti (2008) found that $\mathrm{O}_{3}$ sensitivity among different tree species was associated with LMA. This conclusion was further validated in recent studies including a larger number of woody species (Li et al., 2016; Zhang et al., 2012). Larger LMA may be attributed to a larger density of mesophyll tissues and/or leaf thickness (Wieser et al., 2002). In contrast, lower LMA contributes to higher $\mathrm{O}_{3}$ sensitivity due to less apoplastic fraction in the leaves (Li et al., 2016; Niinemets, 1999). The tested cultivars consisted of nectarines and white peaches, and there were significant differences in the abaxial epidemis, palisade parenchyma and spongy parenchyma thicknesses among these 13 cultivars (Table 2). Thus, it can be inferred that LMA not only may be one key parameter to determine plant sensitivity to $\mathrm{O}_{3}$ among different woody species, but also among different cultivars with different leaf traits for the same species.

Besides the structural leaf traits i.e. LMA, the biochemical parameters, such as activities of SOD, APX and A-SOD, A-APX also played a role in the $\mathrm{O}_{3}$ sensitivity among peach cultivars, as indicated by the significant correlation with AOT40_injury, and the reduction in $A_{\text {sat }}$ (Table 9). The activities of SOD and APX on a mass basis represent inherent physiological and biochemical features among cultivars. The different activities of SOD and APX among peach cultivars determined their different tolerance to $\mathrm{O}_{3}$. Feng et al. (2016) also found similar results among different winter wheat cultivars investigated in an $\mathrm{O}_{3}$-FACE. In addition, the activities of A-SOD and A-APX on a leaf-area basis were also significantly related to $\mathrm{O}_{3}$ sensitivity among cultivars, suggesting that effective $\mathrm{O}_{3}$ uptake contributes to the $\mathrm{O}_{3}$ sensitivity among cultivars when considering both stomatal $\mathrm{O}_{3}$ uptake and leaf detoxification (Wieser et al., 2002; Wrzaczek et al., 2013).

In general, stomatal $\mathrm{O}_{3}$ uptake mainly depends on the $\mathrm{O}_{3}$ concentration at the leaf surface and stomata conductance. Therefore, stomatal properties may also play an important role in determining $\mathrm{O}_{3}$ sensitivity among species or cultivars. However, in our study, neither stomatal structure (stomatal area and density) nor $g_{s}$ were significant correlation with AOT40_injury and with reduction in $A_{\text {sat }}$, although $g_{s}$ was measured many times. It suggests that both stomatal structure and $g_{s}$ does not contribute to the different sensitivity to $\mathrm{O}_{3}$ among selected cultivars. Similar findings were reported in the tree species and wheat cultivars (Feng et al., 2016; Li et al., 2016; Zhang et al., 2012). Interestingly, there were significant negative correlations between $g_{s} /$ LMA, i.e. the $g_{s}$ for leaf ozone

Table 7

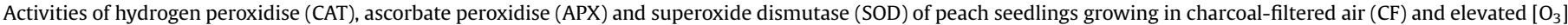
$\left(\mathrm{E}-\mathrm{O}_{3}\right)$. Data are shown as Mean $\pm \mathrm{SE}(\mathrm{n}=3)$; different letters indicate statistical differences (Turkey's test, $P<0.05$ ).

\begin{tabular}{|c|c|c|c|c|c|c|}
\hline \multirow[t]{2}{*}{ Cultivars } & \multicolumn{2}{|c|}{$\mathrm{CAT}\left(\mathrm{U} \mathrm{g}^{-1} \mathrm{FW}\right)$} & \multicolumn{2}{|c|}{$\mathrm{APX}\left(\mathrm{U} \mathrm{g}^{-1} \mathrm{FW}\right)$} & \multicolumn{2}{|c|}{$\mathrm{SOD}\left(\mathrm{U} \mathrm{g}^{-1} \mathrm{FW}\right)$} \\
\hline & $\mathrm{CF}$ & $\mathrm{E}-\mathrm{O}_{3}$ & $\mathrm{CF}$ & $\mathrm{E}-\mathrm{O}_{3}$ & $\mathrm{CF}$ & $\mathrm{E}-\mathrm{O}_{3}$ \\
\hline GH2 & $136 \pm 14.9 a$ & $228 \pm 111 a$ & $85.8 \pm 34.1$ & $201 \pm 50.4$ & $288 \pm 73.9 \mathrm{a}$ & $436 \pm 97.7 a$ \\
\hline$J Y$ & $68.5 \pm 15.5 a$ & $77.4 \pm 12.9 a$ & $180 \pm 9.17$ & $173 \pm 99.8$ & $318 \pm 25.4 a$ & $326 \pm 50.6 a$ \\
\hline LH9 & $49.5 \pm 13.3 a$ & $94.9 \pm 3.67 a$ & $255 \pm 102$ & $241 \pm 19.4$ & $270 \pm 32.8 a$ & $370 \pm 117 a$ \\
\hline LHC & $27.1 \pm 1.83 a$ & $97.8 \pm 18.5 a$ & $86.6 \pm 29.6$ & $144 \pm 60.8$ & $324 \pm 11.3 a$ & $413 \pm 90.0 a$ \\
\hline W24 & $51.4 \pm 9.84 a$ & $200 \pm 90.0 a$ & $156 \pm 21.9$ & $228 \pm 50.8$ & $314 \pm 55.4 a$ & $294 \pm 70.6 a$ \\
\hline$C J$ & $72.9 \pm 21.1 \mathrm{a}$ & $66.5 \pm 34.0 \mathrm{a}$ & $187 \pm 19.9$ & $88.2 \pm 23.1$ & $355 \pm 40.6 a$ & $311 \pm 23.0 a$ \\
\hline$L J Y$ & $99.0 \pm 52.2 \mathrm{a}$ & $167 \pm 18.0 a$ & $157 \pm 80.2$ & $215 \pm 75.6$ & $286 \pm 54.0 \mathrm{a}$ & $385 \pm 75.0 a$ \\
\hline$R G 27$ & $48.5 \pm 20.7 a$ & $65.9 \pm 21.6 a$ & $139 \pm 25.9$ & $207 \pm 90.2$ & $312 \pm 39.5 a$ & $491 \pm 112 a$ \\
\hline 76 & $108 \pm 27.5 a$ & $112 \pm 23.0 a$ & $220 \pm 49.1$ & $169 \pm 35.9$ & $312 \pm 14.0 a$ & $400 \pm 81.4 a$ \\
\hline$Z C$ & $49.1 \pm 19.8 a$ & $188 \pm 19.6 a$ & $186 \pm 42.9$ & $280 \pm 104$ & $307 \pm 25.0 a$ & $209 \pm 62.8 a$ \\
\hline$D D T$ & $81.6 \pm 38.0 a$ & $73.6 \pm 14.1 \mathrm{a}$ & $105 \pm 35.1$ & $154 \pm 45.6$ & $223 \pm 12.9 a$ & $361 \pm 69.6 a$ \\
\hline RG29 & $64.3 \pm 39.2 \mathrm{a}$ & $54.6 \pm 11.0 \mathrm{a}$ & $89.9 \pm 22.5$ & $110 \pm 23.5$ & $300 \pm 44.5 a$ & $402 \pm 76.2 a$ \\
\hline$W C$ & $148 \pm 81.6 a$ & $175 \pm 52.4 a$ & $223 \pm 32.5$ & $139 \pm 40.0$ & $414 \pm 30.6 a$ & $276 \pm 78.4 a$ \\
\hline \multicolumn{7}{|l|}{ ANOVA } \\
\hline $\mathrm{O}_{3}$ & $<0.001$ & & 0.340 & & 0.044 & \\
\hline Cultivars & 0.052 & & 0.252 & & 0.788 & \\
\hline $\mathrm{O}_{3}{ }^{*}$ Cultivars & 0.321 & & 0.659 & & 0.290 & \\
\hline
\end{tabular}


Table 8

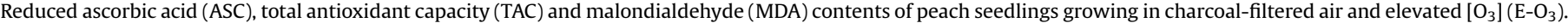
Data are shown as Mean \pm SE $(n=3)$; different letters indicate statistical differences (Turkey's test, $P<0.05)$.

\begin{tabular}{|c|c|c|c|c|c|c|}
\hline \multirow[t]{2}{*}{ Cultivars } & \multicolumn{2}{|c|}{$\mathrm{ASC}\left(\mu \mathrm{mol} \mathrm{g}{ }^{-1} \mathrm{FW}\right)$} & \multicolumn{2}{|c|}{$\mathrm{TAC}\left(\mu \mathrm{mol} \mathrm{g}^{-1} \mathrm{FW}\right)$} & \multicolumn{2}{|c|}{$\mathrm{MDA}\left(\mathrm{nmol} \mathrm{g}^{-1} \mathrm{FW}\right)$} \\
\hline & $\mathrm{CF}$ & $\mathrm{E}-\mathrm{O}_{3}$ & $\mathrm{CF}$ & $\mathrm{E}-\mathrm{O}_{3}$ & $\mathrm{CF}$ & $\mathrm{E}-\mathrm{O}_{3}$ \\
\hline GH2 & $22.5 \pm 5.58 a$ & $7.53 \pm 1.38 a$ & $189 \pm 12.6 a$ & $284 \pm 40.8 a$ & $30.0 \pm 3.19 b$ & $57.6 \pm 2.51 \mathrm{ab}$ \\
\hline$J Y$ & $20.5 \pm 6.16 a$ & $9.21 \pm 3.11 a$ & $228 \pm 53.4 a$ & $254 \pm 81.3 a$ & $32.4 \pm 5.39 a b$ & $46.8 \pm 15.2 \mathrm{ab}$ \\
\hline LH9 & $11.3 \pm 1.07 a$ & $16.9 \pm 0.89 a$ & $168 \pm 21.3 a$ & $289 \pm 13.1 a$ & $42.3 \pm 8.83 a b$ & $66.1 \pm 9.31 a$ \\
\hline$L H C$ & $15.7 \pm 3.81 a$ & $9.90 \pm 2.03 a$ & $240 \pm 94.8 a$ & $235 \pm 4.28 a$ & $38.1 \pm 7.41 \mathrm{ab}$ & $43.5 \pm 6.74 a b$ \\
\hline W24 & $13.7 \pm 1.64 a$ & $11.7 \pm 1.93 a$ & $230 \pm 37.3 a$ & $242 \pm 15.8 a$ & $43.6 \pm 5.94 a b$ & $46.7 \pm 11.1 \mathrm{ab}$ \\
\hline$C J$ & $14.8 \pm 3.57 a$ & $8.74 \pm 2.56 a$ & $146 \pm 38.5 a$ & $367 \pm 65.1 a$ & $36.9 \pm 5.33 a b$ & $56.3 \pm 8.62 a b$ \\
\hline$L J Y$ & $20.0 \pm 3.48 a$ & $12.8 \pm 2.40 \mathrm{a}$ & $264 \pm 5.16 a$ & $333 \pm 54.2 a$ & $40.2 \pm 0.44 a b$ & $59.5 \pm 2.37 a b$ \\
\hline$R G 27$ & $18.5 \pm 3.78 a$ & $12.6 \pm 3.39 a$ & $222 \pm 22.4 a$ & $196 \pm 33.7 a$ & $43.8 \pm 3.60 a b$ & $55.1 \pm 5.83 a b$ \\
\hline 76 & $13.8 \pm 0.77 a$ & $10.7 \pm 0.52 a$ & $173 \pm 24.4 a$ & $242 \pm 46.4 a$ & $40.7 \pm 3.23 a b$ & $46.0 \pm 7.79 a b$ \\
\hline$Z C$ & $12.8 \pm 1.20 \mathrm{a}$ & $16.2 \pm 0.71 a$ & $167 \pm 29.4 a$ & $170 \pm 12.7 a$ & $42.7 \pm 4.55 \mathrm{ab}$ & $42.2 \pm 6.20 a b$ \\
\hline$D D T$ & $12.8 \pm 1.34 a$ & $13.9 \pm 1.67 a$ & $190 \pm 28.7 a$ & $342 \pm 58.2 a$ & $29.5 \pm 2.16 b$ & $42.1 \pm 3.06 a b$ \\
\hline$R G 29$ & $13.6 \pm 2.92 a$ & $12.7 \pm 0.38 a$ & $326 \pm 91.6 a$ & $216 \pm 44.2 \mathrm{a}$ & $36.0 \pm 6.36 \mathrm{ab}$ & $44.2 \pm 2.79 a b$ \\
\hline$W C$ & $16.7 \pm 1.50 \mathrm{a}$ & $14.3 \pm 2.44 a$ & $257 \pm 37.8 a$ & $288 \pm 31.7 a$ & $39.8 \pm 4.22 \mathrm{ab}$ & $43.4 \pm 2.54 a b$ \\
\hline \multicolumn{7}{|l|}{ ANOVA } \\
\hline $\mathrm{O}_{3}$ & 0.001 & & 0.006 & & $<0.001$ & \\
\hline Cultivars & 0.872 & & 0.379 & & 0.306 & \\
\hline $\mathrm{O}_{3}{ }^{*}$ Cultivars & 0.031 & & 0.084 & & 0.541 & \\
\hline
\end{tabular}

Table 9

Pearson coefficient $(r)$ and levels of significance ( $P$ value) in the correlations between parameters in $\mathrm{CF}$ plants at the end of the experiment and the AOT40 at the initial $\mathrm{O}_{3}$ symptom onset (AOT40_injury), reduction in $A_{\text {sat }}$, respectively $(\mathrm{n}=13$ ). The symbols ${ }^{* *}$ and ${ }^{*}$ indicate significances at $P<0.01$ and $P<0.05$, respectively.

\begin{tabular}{llllll}
\hline & \multicolumn{2}{l}{ AOT40_injury } & & \multicolumn{2}{l}{ Reduction in $A_{\text {sat }}$} \\
\cline { 2 - 3 } \cline { 5 - 6 } & $\mathrm{r}$ & $P$ & & $\mathrm{r}$ & $P$ \\
\hline SA & 0.060 & 0.435 & & -0.237 & 0.218 \\
SD & 0.142 & 0.347 & & 0.020 & 0.475 \\
$g_{s}$ & 0.455 & 0.093 & & -0.252 & 0.406 \\
LMA & $\mathbf{0 . 7 2 8}^{* *}$ & $\mathbf{0 . 0 0 9}$ & & $-\mathbf{0 . 6 4 4}^{*}$ & $\mathbf{0 . 0 1 8}$ \\
$g_{s} /$ LMA & 0.275 & 0.221 & & $-\mathbf{0 . 6 3 7}^{* *}$ & $\mathbf{0 . 0 1 0}$ \\
$g_{s} /$ A-TAC & 0.498 & 0.072 & & -0.371 & 0.106 \\
TAC & -0.219 & 0.272 & & -0.446 & 0.127 \\
ASC & 0.459 & 0.091 & & 0.105 & 0.367 \\
A-TAC & 0.109 & 0.382 & & -0.630 & $\mathbf{0 . 0 1 0}$ \\
A-ASC & -0.129 & 0.338 & & -0.129 & 0.338 \\
CAT & -0.100 & 0.784 & & -0.096 & 0.377 \\
APX & -0.036 & 0.461 & & $\mathbf{0 . 4 7 8}$ & \\
SOD & 0.152 & 0.338 & & $-\mathbf{0 . 5 3 3}$ & $\mathbf{0 . 0 4 9}$ \\
A-CAT & 0.027 & 0.470 & -0.178 & $\mathbf{0 . 0 3 0}$ \\
A-APX & $\mathbf{0 . 5 4 9}^{*}$ & $\mathbf{0 . 0 5 0}$ & 0.175 & 0.281 \\
A-SOD & $\mathbf{0 . 6 7 2}^{*}$ & $\mathbf{0 . 0 1 7}$ & $-\mathbf{0 . 7 4 2}^{* *}$ & 0.284 \\
\hline
\end{tabular}

SA: stomatal area, SD: stomatal density, $g_{s}$, stomatal conductance, LMA: leaf mass per area, TAC: total antioxidant capacity, ASC: reduced ascorbic acid, A-TAC: areabased TAC, A-ASC: area-based ASC, A-CAT/A-APX/A-SOD: area-based hydrogen peroxidise/ascorbate peroxidise/superoxide dismutase.

uptake expressed per unit leaf mass, and a reduction in $A_{\text {sat }}$ $(P<0.01)$. The opposite result suggests that neither the leaf areabased $\mathrm{O}_{3}$ flux index nor the mass-based ozone flux index accounts for the different $\mathrm{O}_{3}$ sensitivity among peach cultivars.

\section{Conclusions}

In this study, the eco-physiological responses to elevated $\mathrm{O}_{3}$ among 13 cultivars of peach seedlings were investigated in field open-top chambers. The cultivars showing visible foliar symptoms earlier also exhibited larger reductions in $A_{\text {sat }}$. Among the tested cultivars, three distinct groups with respect to $\mathrm{O}_{3}$ sensitivity could be identified: sensitive cultivars (GH2, JY, LHC and LH9), intermediate cultivars (CJ,W24, LJY, RG27, 76 and $Z C$ ) and resistant cultivars ( $R G 29, D D T$ and $W C$ ) based on symptom onset timing. The white peach cultivars were more sensitive to $\mathrm{O}_{3}$ than nectarine cultivars. LMA and the activities of antioxidant enzymes (SOD, APX and A-
SOD, A-APX) rather than stomatal parameters (stomatal area, density and $g_{s}$ ) or the antioxidant (ASC and A-ASC) contributed significantly to the different $\mathrm{O}_{3}$ sensitivity among the 13 cultivars.

\section{Acknowledgements}

This study has been funded by Natural Sciences Foundation of Beijing (No. 6162021), Key Laboratory of Urban Agriculture (North) of Ministry of Agriculture, China (2015001, 2016001) and the Hundred Talents Program, Chinese Academy of Sciences. We thank Dr. Vicent Calatayud for the English improvement.

\section{References}

Akhtar, N., Yamaguchi, M., Inada, H., Hoshino, D., Kondo, T., Izuta, T., 2010. Effects of ozone on growth, yield and leaf gas exchange rates of two Bangladeshi cultivars of wheat (Triticum aestivum L.). Environ. Pollut. 158, 1763-1767.

Badiani, M. Lorenzini, G. Paolacci, A.R. Varvaro, L, 1993. Ozone enhances the infection of peach leaves by the rust fungus Tranzschelia pruni-spinosae. Fresenius Environ. Bull. 2, 596-601.

Badiani, M., Fuhrer, J., Paolacci, A.R., Giovannozzi Sermanni, G., 1996. Deriving critical levels for ozone effects on peach trees (Prunus persica (L.) Batsch) grown in open-top chambers in Central Italy. Fresenius Environ. Bull. 5, 594-603.

Benzie, I.F.F., Strain, J.J., 1996. The ferric reducing ability of plasma (FRAP) as a measure of "antioxidant power": the FRAP assay. Anal. Biochem. 239, 70-76.

Betzelberger, A.M., Gillespie, K.M., Mcgrath, J.M., Koester, R.P., Nelson, R.L., Ainsworth, E.A., 2010. Effects of chronic elevated ozone concentration on antioxidant capacity, photosynthesis and seed yield of 10 soybean cultivars. Plant Cell Environ. 33, 1569-1581.

Burkey, K.O., Eason, G., Fiscus, E.L., 2003. Factors that affect leaf extracellular ascorbic acid content and redox status. Physiol. Plant. 117, 51-57.

Bussotti, F., 2008. Functional leaf traits, plant communities and acclimation processes in relation to oxidative stress in trees: a critical overview. Glob. Change Biol. 14, 2727-2739.

Calatayud, V., Cerveró, J., Sanz, M.J., 2007. Foliar, physiologial and growth responses of four maple species exposed to ozone. Water Air Soil Pollut. 185, 239-254.

Calatayud, V., Marco, F., Cerveró, J., Sánchez-Peña, G., Sanz, M.J., 2010. Contrasting ozone sensitivity in related evergreen and deciduous shrubs. Environ. Pollut. $158,3580-3587$.

Calatayud, V., Cerveró, J., Calvo, E., García-Breijo, F.J., Reig-Armiñana, J., Sanz, M.J., 2011. Responses of evergreen and deciduous Quercus species to enhanced ozone levels. Environ. Pollut. 159, 55-63.

Cooper, O.R., Parrish, D.D., Ziemke, J., Balashov, N.V., Cupeiro, M., Galbally, I.E., Gilge, S., Horowitz, L., Jensen, N.R., Lamarque, J.F., 2014. Global distribution and trends of tropospheric ozone: an observation-based review. Elem. Sci. Anthropocene 2, 000029.

Dizengremel, P., Le, T.D., Hasenfratzsauder, M.P., Vaultier, M.N., Bagard, M., Jolivet, Y., 2009. Metabolic-dependent changes in plant cell redox power after ozone exposure. Plant Biol. 11 (Suppl. 1), 35-42.

FAOstat, 2014. Available from: http://faostat.fao.org.

Feng, Z., Hu, E., Wang, X., Jiang, L., Liu, X., 2015. Ground-level $\mathrm{O}_{3}$ pollution and its impacts on food crops in China: a review. Environ. Pollut. 199, 42-48. 
Feng, Z., Pang, J., Nouchi, I., Kobayashi, K., Yamakawa, T., Zhu, J., 2010. Apoplastic ascorbate contributes to the differential ozone sensitivity in two varieties of winter wheat under fully open-air field conditions. Environ. Pollut. 158, 3539-3545.

Feng, Z., Kobayashi, K., 2009. Assessing the impacts of current and future concentrations of surface ozone on crop yield with meta-analysis. Atmos. Environ. 43, 1510-1519.

Feng, Z., Wang, L., Pleijel, H., Zhu, J., Kobayashi, K., 2016. Differential effects of ozone on photosynthesis of winter wheat among cultivars depend on antioxidative enzymes rather than stomatal conductance. Sci. Total Environ. 572, 404-411.

Feng, Z., Pang, J., Kobayashi, K., Zhu, J., Ort, D.R., 2011. Differential responses in two varieties of winter wheat to elevated ozone concentration under fully open-air field conditions. Glob. Change Biol. 17, 580-591.

Feng, Z., Sun, J., Wan, W., Hu, E., Calatayud, V., 2014. Evidence of widespread ozoneinduced visible injury on plants in Beijing, China. Environ. Pollut. 193, 296-301.

Frey, B., Scheidegger, C., Gunthardtgoerg, M.S., Matyssek, R., 1996. The effects of ozone and nutrient supply on stomatal response in birch (Betula pendula) leaves as determined by digital image-analysis and X-ray microanalysis. New Phytol. $132,135-143$.

Gil, M.I., Tomas-Barberan, F.A., Hesspierce, B., Kader, A.A., 2002. Antioxidant capacities, phenolic compounds, carotenoids, and vitamin C contents of nectarine, peach, and plum cultivars from California. J. Agric. Food Chem. 50, 4976-4982.

Gillespie, K.M., Rogers, A., Ainsworth, E.A., 2011. Growth at elevated ozone or elevated carbon dioxide concentration alters antioxidant capacity and response to acute oxidative stress in soybean (Glycine max). J. Exp. Bot. 62, 2667-2678.

Haberer, K., Herbinger, K., Alexou, M., Tausz, M., Rennenberg, H., 2007. Antioxidative defence of old growth beech (Fagus sylvatica) under double ambient $\mathrm{O}_{3}$ concentrations in a free-air exposure system. Plant Biol. 9, 215-226.

Heath, R.L., Packer, L., 1968. Photoperoxidation in isolated chloroplasts : I. Kinetics and stoichiometry of fatty acid peroxidation. Arch. Biochem. Biophys. 125, 189-198.

Hoshika, Y., Katata, G., Deushi, M., Watanabe, M., Koike, T., Paoletti, E., 2015. Ozoneinduced stomatal sluggishness changes carbon and water balance of temperate deciduous forests. Sci. Rep. 5, 9871.

Intergovernmental Panel on Climate Change (IPCC), 2013. Fifth Assessment Report. http://www.ipcc.ch/report/ar5/index.shtml.

Kontunen-Soppela, S., Riikonen, J., Ruhanen, H., Brosché, M., Somervuo, P. Peltonen, P., Kangasjärvi, J., Auvinen, P., Paulin, L., Keinänen, M., 2010. Differential gene expression in senescing leaves of two silver birch genotypes in response to elevated $\mathrm{CO}_{2}$ and tropospheric ozone. Plant Cell Environ. 33, 1016-1028.

Li, P., Calatayud, V., Gao, F., Uddling, J., Feng, Z., 2016. Differences in ozone sensitivity among woody species are related to leaf morphology and antioxidant levels. Tree Physiol. 36, 1105-1116.

Lichtenthaler, H.K., 1987. [34] Chlorophylls and carotenoids: pigments of photosynthetic biomembranes. Methods Enzym. 148, 350-382.

Liu, M.Z., Nurbayi, A., Pan, X.L., 2005. The method of extracting the leaf stomata of plants by Nail Polish. Bull. Biol. 40, 44-44, (in Chinese).

LRTAP Convention, 2010. Mapping Manual 2004. Manual on Methodologies and Criteria for Modeling and Mapping Critical Loads \& Levels and Air Pollution Effects, Risk and Trends (Chapter 3). Mapping critical levels for vegetation, 2010 revision. Available from. http://icpvegetation.ceh.ac.uk.

Luwe, M., Heber, U., 1995. Ozone detoxification in the apoplasm and symplasm of spinach, broad bean and beech leaves at ambient and elevated concentrations of ozone in air. Planta 197, 448-455.

Matyssek, R., Wieser, G., Ceulemans, R., Rennenberg, H., Pretzsch, H., Haberer, K., Low, M., Nunn, A.J., Werner, H., Wipfler, P., Osswald, W., Nikolova, P., Hanke, D.E., Kraigher, H., Tausz, M., Bahnweg, G., Kitao, M., Dieler, J., Sandermann, H., Herbinger, K., Grebenc, T., Blumenrother, M., Deckmyn, G., Grams, T.E., Heerdt, C., Leuchner, M., Fabian, P., Haberle, K.H., 2010. Enhanced ozone strongly reduces carbon sink strength of adult beech (Fagus sylvatica)resume from the free-air fumigation study at Kranzberg Forest. Environ. Pollut.
158, 2527-2532.

Mccool, P.M., Musselman, R.C., 1990. Impact of ozone on growth of peach, apricot, and almond. Hortscience A Publ. Am. Soc. Hortic. Sci. 25, 1384-1385.

Mckee, I.F., Eiblmeier, M., Polle, A., 1997. Enhanced ozone-tolerance in wheat grown at an elevated $\mathrm{CO}_{2}$ concentration: ozone exclusion and detoxification. New Phytol. 137, 275-284.

Nali, C., Paoletti, E., Marabottini, R., Rocca, G.D., Lorenzini, G., Paolacci, A.R. Ciaffi, M., Badiani, M., 2004. Ecophysiological and biochemical strategies of response to ozone in Mediterranean evergreen broadleaf species. Atmos. Environ. 38, 2247-2257.

Niinemets, Ü., 1999. Components of leaf dry mass per area: thickness and density Alter leaf photosynthetic capacity in reverse directions in woody plants. New Phytol. 144, 35-47.

Paoletti, E., 2006. Impact of ozone on Mediterranean forests: a review. Environ. Pollut. 144, 463-474.

Paoletti, E., Schaub, M., Matyssek, R., Wieser, G., Augustaitis, A., Bastrup-Birk, A.M., Bytnerowicz, A., Gunthardt-Goerg, M.S., Muller-Starck, G., Serengil, Y., 2010. Advances of air pollution science: from forest decline to multiple-stress effects on forest ecosystem services. Environ. Pollut. 158, 1986-1989.

Saitanis, C.J., Karandinos, M.G., 2002. Effects of ozone on tobacco (Nicotiana tabacum L.) varieties. J. Agron. Crop Sci. 188, 51-58.

Subrahmanyam, D., Rathore, V.S., 2000. Influence of manganese toxicity on photosynthesis in Ricebean (Vigna umbellata) seedlings. Photosynthetica 38, 449-453.

Wang, J., Zeng, Q., Zhu, J., Chen, C., Liu, G., Tang, H., 2014a. Apoplastic antioxidant enzyme responses to chronic free-air ozone exposure in two different ozonesensitive wheat cultivars. Plant Physiol. Biochem. 82, 183-193.

Wang, J., Zhu, J., Zeng, Q., Liu, G., 2014b. Phenolic compounds and antioxidant ability responses to experimental free-air ozone exposure in two wheat cultivars. Bull. Environ. Contam. Toxicol. 93, 625-631.

Wang, L., Pang, J., Feng, Z., Zhu, J., Kobayashi, K., 2015. Diurnal variation of apoplastic ascorbate in winter wheat leaves in relation to ozone detoxification. Environ. Pollut. 207, 413-419.

Wang, Y., Hao, J., Mcelroy, M.B., Munger, J.W., Ma, H., Nielsen, C.P., Zhang, Y., 2010 Year round measurements of $\mathrm{O}_{3}$ and $\mathrm{CO}$ at a rural site near Beijing: variations in their correlations. Tellus 62, 228-241.

Wang, Y., Konopka, P., Liu, Y., Chen, H., Müller, R., Ger, F.P., Riese, M., Cai, Z., Lü, D. 2012. Tropospheric ozone trend over Beijing from 2002-2010: ozonesonde measurements and modeling analysis. Atmos. Chem. Phys. 12, 8389-8399.

Wieser, G., Tegischer, K., Tausz, M., HBerle, K.H., Grams, T.E.E., Matyssek, R., 2002. Age effects on Norway spruce (Picea abies) susceptibility to ozone uptake: a novel approach relating stress avoidance to defense. Tree Physiol. 22, 583-590.

Wittig, V.E., Ainsworth, E.A., Long, S.P., 2007. To what extent do current and projected increases in surface ozone affect photosynthesis and stomatal conduc tance of trees? A meta-analytic review of the last 3 decades of experiments. Plant Cell Environ. 30, 1150-1162.

Wittig, V.E., Ainsworth, E.A., Naidu, S.L., Karnosky, D.F., Long, S.P., 2009. Quantifying the impact of current and future tropospheric ozone on tree biomass, growth, physiology and biochemistry: a quantitative meta-analysis. Glob. Change Biol. $15,396-424$

Wrzaczek, M., Brosché, M., Kangasjärvi, J., 2013. ROS signaling loops - production, perception, regulation. Curr. Opin. Plant Biol. 16, 575-582.

Yin, Y., Li, C., Ma, G., Cui, Z., 2004. Ozone concentration distribution of urban. Environ. Sci. 25, 16-20 (in Chinese)

Yuan, X., Calatayud, V., Jiang, L., Manning, W.J., Hayes, F., Tian, Y., Feng, Z., 2015. Assessing the effects of ambient ozone in China on snap bean genotypes by using ethylenediurea (EDU). Environ. Pollut. 205, 199-208.

Zhang, W., Feng, Z., Wang, X., Niu, J., 2012. Responses of native broadleaved woody species to elevated ozone in subtropical China. Environ. Pollut. 163, 149-157.

Zhang, W., Feng, Z., Wang, X., Niu, J., 2014. Elevated ozone negatively affects photosynthesis of current-year leaves but not previous-year leaves in evergreen Cyclobalanopsis glauca seedlings. Environ. Pollut. 184, 676-681. 